\title{
APLICAÇÕES DA FUNÇÃO PROMOCIONAL NA RESPONSABILIDADE CIVIL AMBIENTAL
}

\author{
APPLICATIONS OF PROMOTIONAL FUNCTION ON ENVIRONMENTAL TORT LAW
}

\section{Antonio dos Reis Júnior ${ }^{1}$}

RESUMO: O presente artigo propõe um espaço de reflexão à releitura, de caráter funcional, em torno das funções da responsabilidade civil. Intenciona difundir a nova função que, conectada à finalidade última do instituto, de viés marcadamente ético, apresenta-se como modelo de estímulos à reparação espontânea do dano. É o que aqui se designa de função promocional da responsabilidade civil, cuja existência tem o condão de aperfeiçoar o sistema de proteção da(s) vítima(s), conferindo mais instrumentos para o tratamento da lesão causada. Como nova fronteira da solidariedade e na esteira da máxima efetividade dos direitos, busca-se, afinal, a satisfação eficaz e eficiente do interesse atual da(a) vítima(s) no momento posterior ao dano, cujo um dos enfoques de maior relevância se concentra na tutela dos interesses metaindividuais, marcadamente da proteção dos danos ambientais.

\begin{abstract}
This article proposes a reflection space for rereading around the functions of tort law. Intends to identify the crisis aspects of the primary responsibility function (compensatory); Intends to spread the new function which, connected to the ultimate purpose of the institute, with a markedly ethical bias, presents itself as a model of stimuli for spontaneous damage repair. That's call promotional function of tort law, whose existence has the ability to improve the protection system of the victim (s), giving more tools for the treatment of the injury caused. As a new frontier of solidarity and in the wake of the maximum effectiveness of rights, we seek, after all, the effective and efficient satisfaction of the current interest of the victim (s) at the moment after the damage, whose one of the most relevant approaches is concentrates on the protection of meta-individual interests, notably the protection of environmental damage.
\end{abstract}

civil Keywords: Tort law. Environmental damage. Promotional function. Aplications.

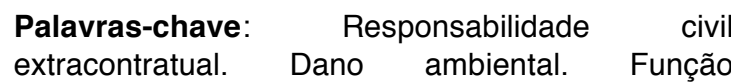
promocional. Aplicações.

SUMÁRIO: 1. Introdução. 2. A função promocional da responsabilidade civil. 2.1. Noção: a necessidade de estímulos à reparação espontânea do dano. 2.2. A função promocional da responsabilidade civil, a máxima efetividade e os confins da transação. 3. Aplicações da função promocional na tutela dos direitos metaindividuais. 4. Desafios à função promocional na tutela ambiental. 5. Conclusões. Referências.

\footnotetext{
${ }^{1}$ Doutor e Mestre em Direito Civil pela Faculdade de Direito da Universidade do Estado do Rio de Janeiro (UERJ). Professor de Direito Civil do Instituto Brasileiro de Mercado de Capitais (IBMEC-Rio). Professor dos Programas de Pós-Graduação lato sensu da PUC-RJ, CEPED (UERJ) e EMERJ. Diretor Adjunto do Instituto Brasileiro de Estudos de Responsabilidade Civil - IBERC.

Este artigo é inspirado na palestra conferida pelo autor no Congresso de Responsabilidade Civil Ambiental, realizado em 17 de maio de 2019.
} 


\section{INTRODUÇÃO}

A pretensão deste artigo é, com base nas investigações levadas a cabo pelo autor, sob os pilares da metodologia civil-constitucional, difundir a tese da função promocional da responsabilidade civil, apresentando-se, desde já, algumas aplicações em locus de extrema relevância: a tutela do interesse ambiental. Neste desiderato, o objetivo é, especialmente, expor as características da novel função promocional e os seus obstáculos, sobretudo quando se encontra diante de um dano de natureza metaindividual.

Para isso, serão abordados os fundamentos da novel função, amparados na ideia de que o Direito persegue, ao lado de uma função meramente coercitiva, uma outra função designada de função promocional. Em seguida, apresentar-se-á a delimitação de seu conteúdo, distinguindo a finalidade promocional das demais funções (reparatória-compensatória, punitiva e preventiva). Finalmente, buscará traçar as suas primeiras aplicações, que na delimitação deste artigo terá como ambiente a tutela coletiva ambiental.

Com isso, acredita-se que a conformação global da responsabilidade civil, apoiada na tríplice função preventiva-reparatória-promocional, uma vez aperfeiçoada, é arranjo dotado de aptidão concreta para, no âmbito de seus domínios, mitigar a angústia da pessoa humana contemporânea. Amparados nos valores elementares da dignidade e da solidariedade, são capazes de aperfeiçoar o exercício da liberdade humana, conferindo maior estabilidade, segurança e harmonia social. E mais: uma vez implementados em sua máxima medida, dedicam à pessoa concreta os instrumentos ideais para a perseguição da plena satisfação dos interesses juridicamente protegidos.

\section{A FUNÇÃO PROMOCIONAL DA RESPONSABILIDADE CIVIL}

Norberto Bobbio $^{2}$, na propositura de uma concepção funcionalista do direito ${ }^{3}$,

\footnotetext{
${ }^{2}$ BOBBIO, Norberto. Da estrutura à função: novos estudos de teoria do direito. Tradução de Daniela Beccaccia Versiani. Barueri: Manole, 2007.

${ }^{3}$ Ainda que a funcionalização do direito seja uma característica marcante da metodologia do direito civilconstitucional, é necessário consignar que não se trata de um novo modo de compreender o direito. Em seus primórdios, quando se falava apenas de "função social", como princípio ou critério de controle da autonomia, já se trabalhava com a releitura da teoria individualista dos direitos subjetivos. Para Léon Duguit, um dos percussores da chamada funcionalização do direito, a vontade individual só fazia sentido na coletividade, sendo a solidariedade um fato social irrefutável, que merecia tutela na ordem jurídica. Em suas palavras, no exercício de suas vontades individuais, o home se apega com solidariedade a outros homens, como representação do que provavelmente tenha sido um dos primeiros atos de consciência humana: "une volonté individuelle, même déterminée par un but collectif, reste une volonté individuelle. Qui affirme cette prétendue conscience collective? L'individu. Son affirmation est un acte de conscience individuelle. Que I'individu se saisisse comme solidaire des autres hommes; que le premier acte de la conscience humaine ait été une représentation de la solidarité sociale, c'est possible, c'est même probable" (DUGUIT, Léon. L'état, le droit objectif et la loi positive. Paris: Albert Fontemoing, 1901, pp. 7-8). A evolução dessa vertente resultou numa perspectiva mais ampla de função e funcionalização dos institutos, que não se restringe ao
} 
considerava insuficientes as tradicionais finalidades "protetora" e "repressiva" do ordenamento jurídico, apresentado como um conjunto de normas negativas. ${ }^{4}$ Revelou, neste contexto, que, ao contrário do que antes imaginava a "ciência do direito", 5 o direito positivo se constitui como modelo normativo composto tanto por sanções negativas, quanto por sanções positivas, ainda que estas representassem fenômeno ainda rarefeito. ${ }^{6}$

A finalidade do ordenamento jurídico não se restringe à realização do valor das liberdades individuais. Além de buscar uma sociedade livre, a ordem jurídica visa construir uma sociedade solidária (art. $3^{\circ}$, I da CF). O valor da solidariedade impõe que as partes mantenham relações de cooperação umas com as outras, não apenas no aspecto negativo, mas também no perfil positivo, de promoção dos valores merecedores de tutela. E para alcançar tal desiderato, é útil que a ordem jurídica dê um "empurrão", ou ofereça um "gatilho", para que as relações sociais se desenvolvam na plenitude dos comportamentos desejados. ${ }^{7}$

seu caráter social, indo além, a representar verdadeira "razão genética do instituto", encontrando na sua finalidade essencial o seu real elemento caracterizador, a sua "razão de ser", como se vê em Salvatore Pugliatti: "Non soltanto la struttura per sè conduce inevitabilmente al tipo che si può descrivire, ma non individuare, bensí inoltre funzione esclusivamente è idonea a fungere da criterio d'individuazione: essa, infatti, dà la ragione genetica dello strumento, e la ragione permamente del suo impiego, cioè la ragione d'essere (oltre a quella di essere stato)" (PUGLIATTI, Salvatore. La proprietà nel nuovo diritto. Milano: Giuffrè, 1964, p. 300).

${ }^{4}$ Nas palavras do racionalismo pragmático de Alf Ross, o ordenamento jurídico é o "corpo integrado de regras que determina as condições sob as quais a força física será exercida contra uma pessoa", extraindo, daí, a ideia de coercibilidade e de sanção negativa (ROSS, Alf. Direito e justiça. Tradução de Edson Bini; revisão técnica de Alysson Leandro Mascaro. 2. ed. São Paulo: Edipro, 2007, p. 58).

${ }^{5}$ Movimento dogmático de grande repercussão teórica, o estudo "científico" do direito representava o estopim da doutrina positivista, no sentido investigar o dano normativo (objeto cientificamente analisado) em sua pureza, com as características da neutralidade, generalidade, abstração e universalidade, sem a interferências de outras realidades da ordem social. A obra de maior relevância, no sistema europeu continental, a cumprir tal desiderato é atribuída à Hans Kelsen, onde ele afirma que "a teoria pura do direito é uma teoria do direito positivo - do direito positivo em geral, não de uma ordem jurídica especial (...). Como teoria, quer única e exclusivamente conhecer o seu próprio objeto. Procura responder a esta questão: o que é e como é o Direito? Mas já não lhe importe a questão de saber como deve ser o Direito, ou como deve ele ser feito. É ciência jurídica e não política do Direito" (KELSEN, Hans. Teoria pura do direito. Tradução de João Baptista Machado. 8. ed. São Paulo: Martins Fontes, 2000, p. 1).

${ }^{6}$ Como já salientava Eduardo Talamini, a sanção "não consiste necessariamente na 'realização compulsória de um mal', eis que pode se apresentar sob a forma de um prêmio (concessão de um bem) a quem observa voluntariamente determinada norma jurídica; e, como consequência dos traços anteriores, não é necessariamente reação a um ato ilícito, embora tenha em mira sempre a observância de normas jurídicas" (TALAMINI, Eduardo. Tutela relativa aos deveres de fazer e de não fazer e sua extensão aos deveres de entrega da coisa. São Paulo: Revista dos Tribunais, 2003, p. 169).

${ }^{7}$ A referência ao termo empurrão (ou cutucada) é uma tradução livre de "nudge", a que se referem Cass S. Sunstein e Richard H. Thaler. Segundo eles, o "empurrão" é um perfil da arquitetura da escolha, que altera o comportamento das pessoas de uma forma previsível, sem retirar-lhes as opções ou modificar significativamente seus incentivos econômicos. Em suas palavras: "A nudge, as we will use the term, is any aspect of the choice architecture that alters people's behavior in a predictable way without forbidding any options or significantly changing their economic incentives. To count as a mere nudge, the intervention must be easy and cheap to avoid. Nudges are not mandates. Putting the fruit at eye level counts as a nudge. Banning junk food does not' (SUNSTEIN, Cass S.; THALER, Richard H. Nudge: improving decisions about health, wealth, and happiness. New Haven: Yale University Press, 2008, p. 6). É um conceito essencial à adoção do chamado "paternalismo libertário", expressão da corrente behaviorista, por meio do qual seus defensores creem ser legítimo que as instituições públicas e privadas tentem influenciar o comportamento das pessoas, de modo que caminhem na direção de escolhas que irão melhorar o seu próprio bem-estar. Ademais, sustentam que é possível ainda complementar tal conceito ao de "benevolência libertária", segundo o qual as regras padronizadas, os efeitos contextuais e os pontos de partida sejam direcionados ao melhor interesse de terceiros vulneráveis: "The paternalistic aspect consists in the claim that it is 
Com efeito, dentre os instrumentos normativos aptos a realizar a função promocional do direito, expressa na Constituição - destacando-se, nesta seara, que o constituinte elegeu como objetivo republicano a construção de uma "sociedade livre, justa e solidária" (art. $3^{\circ}, \mathrm{I}$, da CF) -, apresenta-se a técnica vinculada às sanções positivas. No escólio de Bobbio:

\begin{abstract}
"A noção de sanção positiva deduz-se, a contrario sensu, daquela mais bem elaborada de sanção negativa. Enquanto o castigo é uma reação a uma ação má, o prêmio é uma reação a uma ação boa. No primeiro caso, a reação consiste em restituir o mal ao mal; no segundo, o bem ao bem. Em relação ao agente, diz-se, ainda que de modo um tanto forçado, que o castigo retribui, com uma dor, um prazer (o prazer do delito), enquanto o prêmio retribui, com um prazer, uma dor (o esforço pelo serviço prestado). Digo que é um tanto forçado porque não é verdade que o delito sempre traz prazer a quem o pratica nem que a obra meritória seja sempre realizada com sacrifício. Tal como o mal do castigo pode consistir tanto na atribuição de uma desvantagem quanto na privação de uma vantagem, o bem do prêmio pode consistir tanto na atribuição de uma vantagem quanto na privação de uma desvantagem". ${ }^{8}$
\end{abstract}

Esclarece-se, portanto, que uma ordem jurídica positiva, dentro de um contexto constitucional organizado por uma jurisprudência de valores, como sói ocorrer com a Carta de 1988, permite que a coercibilidade do direito, que atua através dos mecanismos de sanção, apresente-se como reação negativa ou positiva ao comportamento de seus atores. ${ }^{9}$ Assim, persegue-se a conduta desejada tanto por meio de arranjos legais que afetarão a esfera pessoal ou patrimonial do agente que descumprir ao comando de atuação conforme a lei (sanções negativas), como por via de uma normativa que premie ou agracie o agente que realizou certos escopos elegidos pelo ordenamento como merecedores de tutela diferenciada, dado o cumprimento de certas finalidades essenciais (sanções positivas). ${ }^{10}$

legitimate for private and public institutions to attempt to influence people's behavior even when third-party effects are absent. In other words, we argue for self-conscious efforts, by private and public institutions, to steer people's choices in directions that will improve the choosers' own welfare. In our understanding, a policy therefore counts as "paternalistic" if it attempts to influence the choices of affected parties in a way that will make choosers better off. Drawing on some well-established findings in behavioral economics and cognitive psychology, we emphasize the possibility that in some cases individuals make inferior decisions in terms of their own welfare-decisions that they would change if they had complete information, unlimited cognitive abilities, and no lack of self-control. In addition, the notion of libertarian paternalism can be complemented by that of libertarian benevolence, by which plan design features such as default rules, framing effects, and starting points are enlisted in the interest of vulnerable third parties. We shall devote some discussion to this possibility" (SUNSTEIN, Cass S.; THALER, Richard H. Libertarian Paternalism Is Not an Oxymoron. Civilistica.com. Revista Eletrônica de Direito Civil, Rio de Janeiro, a. 4, n. 2, 2015, p. 4.). ${ }^{8}$ BOBBIO, Norberto. Da estrutura à função..., cit., pp. 24-25.

9 "Vistos de um ângulo sócio-psicológico, o prêmio e a pena são estabelecidos a fim de transformar o desejo do prêmio e o receio da pena em motivo da conduta socialmente desejada" (KELSEN, Hans. Teoria pura do direito, cit., p. 28).

10 "Se é verdade, de fato, que a recompensa é o meio usado para determinar o comportamento alheio por aqueles que dispõem das reservas econômicas, a isto segue que o Estado, à medida que dispõe de recursos econômicos cada vez mais vastos, venha a se encontrar em condição de determinar o comportamento dos indivíduos, não apenas com o exercício da coação, mas também com o de vantagens de ordem econômica, isto é, desenvolvendo uma função não apenas dissuasiva, mas também, como já foi dito, promocional. Em poucas palavras, essa função é exercida com a promessa de uma vantagem (de natureza econômica) a uma ação desejada, e não com a ameaça de um mal a uma ação indesejada. É 
Para isso, é preciso que a dogmática avance no sentido de identificar os espectros de sanção positiva já previstos no ordenamento, ainda que de modo implícito. Faz-se mister que se desperte a doutrina de seu sono dogmático, ao crer que o estudo das sanções positivas deve ser relegado ao âmbito do direito administrativo, regulatório ou, em termos gerais, às questões de política legislativa. Nada mais obsoleto em termos de teoria da interpretação. Se a norma jurídica é o resultado da interpretação, que não se apoia única e exclusivamente no texto, mas que condensa a realidade dos fatos, os valores socialmente relevantes e diversos interesses merecedores de tutela que estão em jogo, ${ }^{11}$ é possível extrair que, para certos objetivos normativos, o direito positivo já prevê, mesmo que implicitamente, bonificações (prêmios) para quem se comporta em conformidade com a conduta desejada, ainda que de modo inconsciente.

Com apoio nessa ideia de direito, notadamente funcional e de viés axiológico e teleológico, defende-se aqui uma perspectiva de releitura funcional do instituto da responsabilidade civil, reconhecendo nela uma função promocional.

\subsection{NOÇÃO: A NECESSIDADE DE ESTÍMULO À REPARAÇÃO ESPONTÂNEA DO DANO}

A primeira noção apresentada, no sentido de que a responsabilidade civil assume um perfil promocional ao tutelar de modo máximo a pessoa humana, não parece atingir o real sentido técnico da função promocional, por revelar-se insuficiente em termos de concretude, aparentando conteúdo vazio, desprovido de sentido prático-jurídico. ${ }^{12}$

Não se trata de negar que o ordenamento visa à proteção integral da pessoa humana, em todos os seus aspectos, mas apenas de identificar que tal escopo não pode ser confundido com o que caracteriza, tecnicamente, a função promocional da responsabilidade civil. Se tal corrente é adotada, é natural que se entenda que diversas formas de sanções negativas podem alcançar a tutela máxima da pessoa humana, seja porque cumpriram com a regra da reparação integral, seja porque foram além, atribuindo vantagem superior à vítima pela imposição de alguma penalidade adicional ao agente. Mas nenhuma dessas circunstâncias

exercida, pois, pelo uso cada vez mais frequente do expediente das sanções positivas" (BOBBIO, Norberto. Da estrutura à função..., cit., p. 68).

${ }^{11}$ No sentido de que a norma jurídica é um posterius do procedimento de interpretação (resultado interpretativo), e não um prius (como dano pressuposto), cf. PERLINGIERI, Pietro. $O$ direito civil na legalidade constitucional. Tradução de Maria Cristina De Cicco. Rio de Janeiro: Renovar, 2008, pp. 617620; e TEPEDINO, Gustavo. Liberdades, tecnologia e teoria da interpretação. Revista Forense, v. 110, n. 419, Rio de Janeiro: Forense, jan./jun. 2014, p. pp. 77-96.

${ }^{12}$ Não se questiona que o direito patrimonial deve ser funcionalizado ao interesse existencial que compõe a cláusula geral de tutela da pessoa humana. Neste sentido, cf. BODIN DE MORAES, Maria Celina. A caminho de um direito civil-constitucional. Revista Estado, Direito e Sociedade, v. I, p. 1-22, 1991, pp. 1112; e TEPEDINO, Gustavo. Premissas metodológicas para a constitucionalização do direito civil. In: Temas de Direito Civil. Rio de Janeiro: Renovar, 2008. p. 23. Todavia, tal compreensão não revela sequer o real sentido da "função promocional", mesmo em sentido genérico. A formulação fica ainda mais frágil porque não consegue se conectar aos mecanismos próprios da responsabilidade civil, de modo a permitir uma definição autônoma e útil à chamada função promocional da responsabilidade civil. 
revela o conteúdo da função promocional, antes atendendo às demais finalidades já aqui elucidadas: a função reparatória e uma circunstancial função punitiva. Por outro lado, medidas regulatórias, ou administrativas, realizada no âmbito de conferir publicidade às empresas que atuam de modo sustentável, ou de modo geral, que atuam no sentido de evitar a concretização de danos, com o fim de promover o nome do agente de mercado na sociedade parece muito mais ligada ao escopo precaucional. ${ }^{13}$

A corrente seguinte, tecnicamente mais desenvolvida, peca por situar a aludida função promocional à perseguição de finalidades puramente preventivas, ou mesmo associadas à polêmica função punitiva, o que não parece refletir a teleologia última do sistema de responsabilidade civil. ${ }^{14}$ Sabe-se que o direito dos danos é conectado, primariamente, ao viés sancionatório, como reação a um evento danoso, em busca do reequilíbrio perdido, situação reveladora de que o valor a ser perseguido deve, fundamentalmente, ligar-se ao escopo reparatório, ainda que se possa trabalhar, concomitantemente, com a tutela de valores que norteiam os comportamentos preventivos. ${ }^{15}$ Mas, neste caso, a função preventiva já se apresenta como finalidade que se propõe a conferir uma tutela ampla, positiva e negativa, dos interesses juridicamente protegidos, de modo que sejam realizados em que ofendam a esfera jurídica de terceiros, daí a finalidade preventiva. Como já se delineou, ela atua sobre o controle de comportamentos, podendo-se estimular condutas (perfil positivo da função preventiva) ou arbitrar sanções pelo descumprimento dos deveres de cuidado e proteção, independentemente da realização da lesão (perfil negativo da função preventiva).

Em nível teórico, lançam-se, ainda, as seguintes objeções à perspectiva da função promocional como finalidade ligada ao momento preventivo/punitivo: (i) laurear o agente "super

\footnotetext{
${ }^{13}$ Quando se relacionam à questões conexas aos direitos dos danos, os autores ilustram que "seria o caso de conferir ampla publicidade aos atos de pessoas jurídicas que se desenvolvem de modo sustentável, sem agredir o meio ambiente, ou daquelas cujas reclamações por inscrição indevida nos órgãos de proteção ao crédito foram eliminadas ou reduzidas substancialmente, emitindo-se certificados de congratulações para as mesmas e disponibilizando-os em meios de fácil acesso para a população como uma forma de divulgação de seus nomes" (RODRIGUES, Francisco Luciano Lima; VERAS, Gésio de Lima. Dimensão funcional do dano moral no direito civil contemporâneo. Civilistica.com. Revista Eletrônica de Direito Civil, Rio de Janeiro, a. 4, n. 2, 2015, p. 19). Neste caso, parece tratar-se de questão ligada à já referida função preventiva ou de precaução, como mais um instrumento da já aludida função, tornando despicienda a "invenção" de uma nova função (dita promocional) para alcançar finalidade de prevenção de danos.

${ }^{14}$ Quando se fala em teleologia última, quer-se destacar a finalidade derradeira que serve ao fechamento de um círculo virtuoso de funções que elevam a responsabilidade civil ao seu patamar máximo de concretude, eficácia e efetividade. A finalidade preventiva, embora fundamental ao instituto, é ainda uma finalidade prévia e elementar da responsabilidade civil, não ser ela a finalidade "última". Cf. NEVES, António Castanheira. A crise actual da filosofia do direito no contexto da crise global da filosofia: tópicos para a possibilidade de uma reflexiva reabilitação. Coimbra: Coimbra Editora, 2003, p. 104.

${ }^{15}$ Tanto a "exclusão de uma sanção punitiva (a privação de uma desvantagem)", como a "criação de uma espécie de cadastro positivo de louváveis agentes econômicos em todos os setores da atividade econômica - com incentivo em obtenção de financiamentos públicos, redução de juros - capaz de gerar uma percepção positiva da sociedade em termos de imagem, com reflexos patrimoniais e morais para as empresas", em razão de uma prática de "diligência extraordinária" na atividade econômica, a fim de evitar os danos, revela um sentido desassociado da finalidade primária, integrando, em verdade, a própria noção de função preventiva em todas as suas potencialidades (ROSENVALD, Nelson. Funções da responsabilidade civil: a reparação e a pena civil. 3. ed. São Paulo: Saraiva, 2017, p. 161). É que a tutela positiva não é uma exclusividade da função promocional.
} 
diligente" com a exclusão de uma indenização punitiva pressupõe, antes, assumir esta como existente na ordem jurídica positiva, conduzindo a questão ao problema da admissibilidade de uma indenização punitiva autônoma (pena privada), sem que haja prévia instituição por lei; ${ }^{16}$ (ii) "funcionalizar" o perfil promocional da responsabilidade aos atos de prevenção e precaução representa um descolamento de tal função à finalidade primária do direito dos danos (a função reparatória/compensatória); ${ }^{17}$ (iii) a função preventiva, quando possível realizar-se, encontra alguns limites e obstáculos no seu aperfeiçoamento, especialmente nas hipóteses de análise de comportamentos cujos danos deles decorrentes atraiam o regime de responsabilidade objetiva; ${ }^{18}$ (iv) o benefício (prêmio) obtido por uma conduta "extraordinariamente diligente" seria demasiadamente indireto, intangível, o que reduziria o poder de estímulo a ele associado; (v) a função preventiva já abrange o perfil de tutela positivo e negativo em sua essência, tornando-se desnecessário envidar esforços em torno da construção de uma função promocional à função preventiva, sendo mesmo uma tautologia.

Em verdade, assentir com a existência de uma função promocional da responsabilidade civil pressupõe, fundamentalmente, aderir à tese de que (i) a ordem jurídica positiva visa cumprir determinadas finalidades, podendo delas extrair uma teleologia; (ii) em razão disso, os institutos e categorias devem ser interpretados de maneira funcionalizada ao cumprimento de tais finalidades; (iii) os mecanismos normativos, definidores dos comportamentos desejados, pela via da previsão de reação do direito diante da conduta dos sujeitos, apresentam-se de duas formas: sanções negativas e positivas; (iv) a sanção positiva, definida como uma resposta benéfica do ordenamento a um comportamento desejável, que se faz necessário estimular, é admitida no âmbito da responsabilidade civil e extraída do contexto global do sistema; (v) os seus efeitos podem ser revelados mediante uma interpretação teleológica do direito posto, no qual já se pode vislumbrar uma aplicação prática, mesmo sem a existência de uma regulamentação específica; (vi) a sua construção dogmática deve gozar de autonomia suficiente para não se confundir com as demais funções já consagradas, ainda que possa ter relação de dependência com uma delas. ${ }^{19}$

Em cumprimento a este itinerário, já se demonstrou que o direito positivo

\footnotetext{
${ }^{16}$ Essa objeção - de assumir a existência de danos punitivos no Brasil - já foi bem explicitada nos capítulos 2 e 3, supra, e, por todos, em BODIN DE MORAES, Maria Celina. Danos à pessoa humana: uma releitura civil-constitucional dos danos morais. 2. ed. Rio de Janeiro: Processo, 2017, p. 260.

${ }^{17}$ Mais uma vez, é possível imaginar responsabilidade civil sem atuação preventiva, mas o inverso não é possível: não se cogita a existência de um modelo de responsabilidade sem tutela reparatória, com exclusiva atuação prévia, de controle de comportamentos, sem que se imponha o dever de indenizar caso a lesão se efetive.

${ }^{18}$ Como já se acentuou, é necessário esclarecer que a tutela do dano é distinta da tutela preventiva. A responsabilidade objetiva, que diz respeito aos pressupostos para a reparação do dano, não pode ser modelo aplicável à tutela preventiva, que pressupõe a análise (com juízo de reprovabilidade) do comportamento do agente. Eis a razão pela qual a tutela preventiva deve ser sempre de natureza subjetiva. Neste sentido, confira a capítulos 2 e 3, supra, e o que já esclarece ROSENVALD, Nelson. As funções da responsabilidade civil, cit., pp. 242-243.

${ }^{19}$ Permita-se remeter às observações preliminares apresentadas em REIS JÚNIOR, Antonio dos. Por uma função promocional da responsabilidade civil. In: SOUZA, Eduardo Nunes; SILVA, Rodrigo da Guia (Coord.). Controvérsias atuais em responsabilidade civil. São Paulo: Almedina, 2018, p. 597.
} 
contemporâneo, pós-positivista, organiza-se por um conjunto de normas cujo escopo não se resume a garantir o seu próprio cumprimento, numa perspectiva puramente formal, mas vinculado às finalidades materialmente determinadas na Constituição. ${ }^{20}$ Se o direito atende, desta forma, a uma teleologia que se pode extrair da tábua de valores definida na Carta Maior, a responsabilidade civil se vincula a axiologia que não se limita ao aspecto lógico e interno do instituto, mas que se conecta com os valores globais do ordenamento (daí o seu aspecto funcional). ${ }^{21}$

Desta forma, se àquele aspecto interno, inerente ao instituto, que remonta às suas origens e aos alicerces de sustentação de sua existência, emerge a sua finalidade primária (função reparatória/compensatória), como resposta negativa (sanção negativa) do ordenamento a um dano injusto produzido na esfera jurídica de alguém, ${ }^{22}$ o desafio do intérprete é obter o significado de sua finalidade última. ${ }^{23}$ Neste sentido, entende-se por finalidade última aquela que se realiza no escopo global do ordenamento jurídico, como último degrau de concretização do direito, em sua unidade. Tal sentido só pode ser identificado através do reconhecimento de um objetivo final destacado na tábua de valores que compõem o vértice da escala hierárquica do ordenamento, cujo teor encontre perfeita harmonização com a intencionalidade primeira do instituto da responsabilidade civil. ${ }^{24}$ Eis por que a finalidade última da responsabilidade civil só pode estar associada ao comando do art. $3^{\circ}$, I, da CF, que define como "objetivo fundamental" da República Federativa do Brasil "construir uma sociedade livre, justa e solidária". Se a liberdade já encontra lugar como um dos fundamentos de imputação da responsabilidade e a justeza do modelo é de sua própria natureza, calcada nos parâmetros de igualdade e preservação da incolumidade da esfera jurídica alheia (ambos sustentam a finalidade primária da responsabilidade civil), é na solidariedade que se deve desenvolver o conteúdo da última

\footnotetext{
${ }^{20}$ PERLINGIEIRI, Pietro. O direito civil na legalidade constitucional. Rio de Janeiro: Renovar, 2008, pp. 589591.

${ }^{21}$ Nesta direção, acerca do "dano injusto", muito caro ao direito italiano, como já demonstrado no capítulo 1 , supra, notadamente em face da previsão legal do art. 2.043 do Código Civil, leciona ADOLFO DI MAJO que "il concetto di 'danno ingiusto' realizza una 'clausola generale', la quale ha riguardo a tutte le situazioni giuridiche che possono ricondursi alla violazione di principi, anche più generali, come quello di solidarietà, di cui è parola massimamente nella Costituzione (art. 2) ma non solo in essa" (Discorso generale sulla responsabilità civile. In: LIPARI, Nicolò; RESCIGNO, Pietro (Coord.). Diritto civile. Milano: Giuffrè, 2009, v. IV, t. III, p. 23).

${ }^{22}$ Importante reforçar que a ideia de sanção não se confunde com a de punição, ou imposição de pena. Neste sentido, sanção negativa representa, em termos gerais, uma resposta negativa a um comportamento negativo, rejeitado pela ordem jurídica, motivo pelo qual a imputação do dever de indenizar ao responsável representa uma forma de aplicação de uma sanção negativa, mesmo que desprovida de viés punitivo (REALE, Miguel. Filosofia do direito. 12. ed. São Paulo: Saraiva, 1987, p. 673).

${ }^{23}$ Segundo MAFALDA Miranda BARBOSA, a teleologia última da responsabilidade civil corresponde à "intencionalidade que a caracteriza e que lhe comunica um determinado sentido do direito enquanto direito" (Reflexões em torno da responsabilidade civil: teleologia e teleonomologia em debate. Boletim da Faculdade de Direito da Universidade de Coimbra, v. 81, Coimbra: FDUC, 2005, p. 512).

${ }^{24}$ Mais uma vez, saliente-se, a referência à finalidade primária, primeira ou originária não implica superioridade hierárquica do thelos reparatório, em comparação, por exemplo, à finalidade preventiva, mas apenas que ela representa a referência teleológica nuclear do instituto, sem a qual a responsabilidade não encontra razão de ser.
} 
fronteira na teleologia da responsabilidade civil. ${ }^{25}$

Decerto que já são muitos os esforços no sentido de transpor para a solidariedade o fundamento da responsabilidade civil. Como já demonstrado, costuma-se ancorar no valor da solidariedade tanto o movimento de "objetivação" da responsabilidade civil, ${ }^{26}$ quanto a corrente que sustenta o abandono do viés individualista do dever de reparar, por um sistema global de socialização dos riscos e das perdas, ${ }^{27}$ ou mesmo no sentido de fundamentar a expansão dos "novos" danos indenizáveis (ou a seleção de novos interesses dignos de tutela jurídica), ${ }^{28}$ até aqueles que atribuem à solidariedade o fundamento de valor da função preventiva. ${ }^{29}$ Entretanto, aqui se defende uma outra atribuição de sentido ao valor da solidariedade, que revela a finalidade última da responsabilidade civil, na fronteira derradeira de concretização (máxima efetividade) de sua finalidade primária.

$\mathrm{Na}$ busca de seu significado, não é prudente que seja compreendida como contraponto ao valor da liberdade. Antes, deve conviver harmonicamente com ela, delineando, nos confins de sua interseção, o conteúdo daquela e vice-versa. Em outras palavras, não se trata de travar um embate de fundamentos entre liberdade vs solidariedade. Cuida-se de identificar em ambos os valores, de igual peso hierárquico, as finalidades e funções que a responsabilidade civil persegue, numa perspectiva unitária.

Neste raciocínio, compreende-se que a liberdade, como fundamento da responsabilidade civil, influenciada pela solidariedade, só pode ser entendida em contexto interrelacional, não-individualista e não-voluntarista, mas que encontra na pessoa humana o locus de sua atuação, considerando toda a complexidade de interesses que a envolvem, máxime aqueles de natureza existencial. ${ }^{30}$ Ciente de que sua autonomia só pode ser realizada na consideração do Outro, como elemento integrante daquilo que representa a personalidade humana, confere-se à liberdade, assim, um sentido ético (e não moralista), positivo (com senso de dever de conduta),

\footnotetext{
${ }^{25}$ Marcante a passagem de MARIA CELINA BODIN DE MORAES, ao identificar o conteúdo do princípio da solidariedade: "a pessoa humana, no que se difere diametralmente da concepção jurídica de indivíduo, há de ser apreciada a partir da sua inserção no meio social, e nunca como célula autônoma, nunca microcosmo cujo destino e cujas atitudes possam ser diferentes aos destinos e às atitudes dos demais (...). O princípio da solidariedade, ao contrário, é a expressão mais profunda da sociabilidade que caracteriza a pessoa humana. No contexto atual, a Lei Maior determina - ou melhor, exige - que nos ajudemos, mutuamente, a conservar a nossa humanidade porque a construção da sociedade justa, livre e solidária cabe a todos e a cada um de nós" (O princípio da solidariedade. Na medida da pessoa humana. Rio de Janeiro: Renovar, 2008, pp. 264-265).

${ }^{26}$ SALLES, Raquel Bellini. A cláusula geral de responsabilidade objetiva. Rio de Janeiro: Lumen Juris, 2011., p. 61.

${ }^{27}$ SCHEREIBER, Anderson. Novos paradigmas da responsabilidade civil: da erosão dos filtros da reparação à diluição dos danos. 4. ed. São Paulo: Atlas, 2012, p. 30.

${ }^{28}$ RODOTÀ, Stefano. Il problema della responsabilità civile. Milano: Giuffrè, 1967, pp. 89-116.

${ }^{29}$ VENTURI, Thaís Gouveia Pascoaloto. Responsabilidade civil preventiva: a proteção contra a violação dos direitos e a tutela inibitória material. São Paulo: Malheiros, 2014, p. 241.

30 "A pessoa - entendida como conexão existencial em cada indivíduo da estima de si, do cuidado com o outro e da aspiração de viver em instituições justas - é hoje o ponto de confluência de uma pluralidade de culturas, que nela reconhecem a sua própria referência de valores. (...) A pessoa é inseparável da solidariedade: ter cuidado com o outro faz parte do conceito de pessoa. (...) Nesta perspectiva, a solidariedade exprime a cooperação e a igualdade na afirmação dos direitos fundamentais de todos" (PERLINGIERI, Pietro. O direito civil na legalidade constitucional, cit., pp. 460-462).
} 
vinculado à personalidade, que se realiza na comunicação com os demais centros de interesses, ${ }^{31}$ ainda que não se perca de vista o seu sentido negativo, associado à definição de seus limites de atuação, onde a responsabilidade atua como modelo de reação ao dano proveniente de seu indevido exercício. Aqui se observa a finalidade primária da responsabilidade civil: o viés reativo, de resposta, como sanção negativa, a um dano causado por alguém na esfera jurídica alheia.

À solidariedade, por sua vez, deve-se atribuir um novo sentido que não se contraponha à liberdade, mas que se comunique a ela, extraindo dessa relação a finalidade última do instituto. ${ }^{32}$ Nesta direção, a solidariedade exprime também, quando conectada à função primária, um sentido (ligado à ideia de uma liberdade positiva) que convoca os atores envolvidos no evento danoso (que já ocorreu) a movimentarem-se (como senso de dever) do modo mais eficaz possível à realização da reparação/compensação dos danos concretizados na esfera jurídica da vítima. De um lado, convoca o agente à busca pela maneira mais eficiente de reparar ou compensar a vítima. De outro, concretizado o dano, invoca a vítima a abrir os canais de comunicação para a realização de tal desiderato, exigindo-se cooperação de sua parte. Abre-se um canal de diálogo possível e desejável (daí o sentido ético) na ambiência normalmente hostil da responsabilidade extracontratual ou aquiliana, onde agente e vítima não mantinham relações ou vínculos pretéritos. É um passo adiante na escala do avanço civilizatório e comunitário.

Ao remate, no constitucionalismo contemporâneo do pós-guerra, não se pode admitir que o modelo de responsabilidade sirva a escopos individualistas, seja na perspectiva da vítima, seja pela ótica do agente ofensor. É que o valor da pessoa humana representa o centro maior de interesses do ordenamento jurídico, de maneira que a responsabilidade civil só pode fundamentar-se da consideração da pessoa (e não do indivíduo, ou sujeito de direito), na complexidade de seus atributos (patrimoniais e existenciais), como núcleo maior de tutela e critério-mor de conformação do instituto. Assim é que a dignidade, que não se realiza sem liberdade e solidariedade, representa a ideia de ter na pessoa a finalidade do direito, conferindo à responsabilidade civil um caráter ético imanente. A obrigação de indenizar existe em razão do exercício da liberdade, mas não como limite externo desta, senão como componente de

31 "O homem não é mais o indivíduo absoluto, que tem ao seu dispor um mundo objecto manipulável, mas a pessoa convivente, que age no mundo por que é responsável; e por outro lado e consonantemente o direito não é o mero regular do encontro de arbítrios, subjectivamente titulados, que recíproca e mecanicamente se comprimem, mas autenticamente co-instituída exigência de sentido em que a pessoa aceita rever-se" (BRONZE, Pinto. O Visconde de Seabra (um exercício de memória). Boletim da Faculdade de Direito. v. LXXI. Coimbra: Ed. Coimbra, 1995, p. 593). Em conexão com a responsabilidade, MALFADA MIRANDA BARBOSA leciona que "o homem já não pode ser entendido isoladamente, como uma parcela do todo, mas deve ser entendido como um ser que realiza plenamente a dignidade ética na comunicação com os outros semelhantes" (Reflexões em torno da responsabilidade civil..., cit., p. 557).

32 "Não se trata (...) somente de impor limites à liberdade individual, atribuindo inteira relevância à solidariedade social: o princípio cardeal do ordenamento é o da dignidade humana, que se busca atingir através deu uma medida de ponderação que oscila entre os dois valores, ora propendendo para a liberdade, ora para a solidariedade. A resultante dependerá dos interesses envolvidos, de suas consequências perante terceiros, de sua valoração em conformidade com a tábua axiológica constitucional, e determinará a disponibilidade ou indisponibilidade da situação jurídica protegida" (BODIN DE MORAES, Maria Celina. O princípio da solidariedade, cit., pp. 264-265). 
modelação de seu exercício, que exige o cumprimento de deveres (solidariedade). Quanto mais eficazmente forem tais deveres cumpridos (especialmente o dever de reparar ou compensar), melhor para a comunidade na qual as pessoas se inter-relacionam, aproximando-se mais à vítima, em igual medida, de sua reparação integral. ${ }^{33}$

A função promocional da responsabilidade civil, portanto, define-se como finalidade última do direito dos danos, como degrau derradeiro de seu aperfeiçoamento, cujo sentido, conectado à sua finalidade primária, revela-se pelo conjunto de medidas que visam estimular, com amparo na ideia de sanção positiva, a reparação ou compensação espontânea dos danos. ${ }^{34}$

Com fundamento no binômio liberdade negativa-responsabilidade, em sua finalidade primária, o causador do dano é obrigado, com ou sem culpa (conforme seja a responsabilidade subjetiva ou objetiva), a reparar ou compensar a vítima, medindo a indenização pela extensão do dano (sanção negativa). Sendo este o efeito que se impõe, pelo conjunto normativo estabelecido pelo ordenamento jurídico (art. 186, 187 e 927 do Código Civil), cumpre realizá-lo da maneira mais efetiva possível, permitindo-se, assim, extrair a finalidade última da responsabilidade civil, de modo a emanar do sistema jurídico um conjunto de sanções positivas (prêmios ou recompensas), cujo objetivo é estimular a reparação espontânea e eficiente dos danos. Fala-se de um conjunto de efeitos favoráveis ao agente que (atribuindo-lhe uma vantagem ou privando-o de uma desvantagem), uma vez reconhecidos pela doutrina e pela jurisprudência, terão força suficiente para gerar um ambiente inter-relacional ideal, cujo maior beneficiário continuará sendo a própria vítima: pessoa lesada cujo centro de interesses se mantém como aquele mais importante a tutelar. ${ }^{35}$

Contudo, como parte do desafio da doutrina e da jurisprudência, faz-se mister que se elabore critérios seguros de definição das vantagens (ou da redução ou privação das desvantagens) que o agente causador do dano teria, caso decidisse reparar ou compensar, espontânea e rapidamente, de modo eficiente (alcançando a reparação integral), os danos por ele causados.

\subsection{A FUNÇÃO PROMOCIONAL DA RESPONSABILIDADE CIVIL, A MÁXIMA EFETIVIDADE E OS CONFINS DA TRANSAÇÃO}

A função promocional da responsabilidade civil é expressão da finalidade última do

\footnotetext{
${ }^{33}$ É a mesma linha adotada por BODIN DE MORAES, Maria Celina. A constitucionalização do direito civil e seus efeitos sobre a responsabilidade civil. In: Na medida da pessoa humana: estudos de direito civilconstitucional. Rio de Janeiro: Renovar, 2010, pp. 317-342.

${ }^{34}$ Mais uma vez, pede-se a devida licença para remeter a REIS JÚNIOR, Antonio dos. Por uma função promocional da responsabilidade civil, cit., p. 601.

${ }^{35}$ Valiosas as palavras de LOUIS JOSSERAND, para quem "a história da responsabilidade é a história da jurisprudência, e também, de alguma forma, da doutrina: é, mais geralmente, o triunfo do espírito, do senso jurídico" (Evolução da responsabilidade civil. Revista Forense. a. 38. v. 86. Rio de Janeiro, 1941, p. 559).
} 
instituto. Aquela função que se liga às exigências comportamentais e éticas derradeiras, para que as pessoas, no exercício da solidariedade, corrijam seus equívocos espontaneamente, ainda que pela via de um estímulo. Como está ligada umbilicalmente à finalidade primária, pressupõe o dano e se orienta para a sua melhor reparação ou compensação. ${ }^{36}$ Como direciona o foco ao comportamento elogiável (ético) das partes envolvidas, para solver o litígio e restabelecer a harmonia social, não se prende inexoravelmente à exata medida da extensão do dano, ${ }^{37}$ mas ao aspecto subjetivo dos envolvidos: o agente causador quer e se comporta de maneira a compensar de forma célere, eficiente e segura; enquanto a vítima quer e se comporta de modo favorável à resolução rápida, também eficiente e de tal sorte que satisfaça o seu interesse. ${ }^{38}$

Quando se diz que a função promocional é modelo de estímulo à reparação espontânea do dano, faz-se necessário destacar alguns pontos que podem, desde já, sofrer objeções razoáveis. O primeiro deles é o conceito de espontaneidade. A rigor, uma pessoa age espontaneamente quando movida por impulsos próprios (sejam eles de ordem intuitiva ou racional), sem que haja interferência externa na conformação de sua vontade. De fato, essa é a apuração conceitual comum mais precisa, mas que aqui será ressignificada à luz dos valores do ordenamento (dever-ser) e da praxe (ser), de modo a impingir-lhe significado jurídico próprio.

A questão está ligada, impreterivelmente, ao problema da eficácia do direito. Mesmo - autor expoente do positivismo jurídico já afirmou que as normas jurídicas somente permanecem válidas (e, portanto, vigentes) "se esta ordem jurídica é eficaz, quer dizer, enquanto a ordem jurídica (numa consideração global) for eficaz". ${ }^{39}$ Neste caso, a importância da praxe (mundo do ser) na conformação da ordem jurídica positiva (mundo do dever-ser) é de tal grau que se torna condicionante da própria existência válida do direito objetivo, enquanto tal. Sendo assim, faz-se mister compreender o fenômeno do "agir espontâneo" de acordo com as circunstâncias da realidade e pela via dos valores e instrumentos que a ordem positiva põe à disposição do agente causador do dano.

É por essa razão que aqui se considera espontânea tanto a conduta motivada pelo despertar íntimo e pessoal, de raiz puramente religiosa ou moral subjetiva, quanto o comportamento impulsionado pela existência de uma sanção determinada (a qual a pessoa prestou obediência), como senso de dever (ético-moral objetivo ou simplesmente jurídico), ${ }^{40}$

\footnotetext{
${ }^{36}$ A alteração do perfil de satisfação da vítima é um dos traços marcantes que distinguem a função reparatória/compensatória clássica, da função promocional. Enquanto aquela visa a reparação integral, aos moldes tradicionais, esta vislumbra uma ideia ressignifica de reparação integral, no sentido de reparação eficiente e, portanto, suficiente, que satisfaça os interesses da vítima.

${ }^{37}$ Embora a função promocional pressuponha o dano, não se rende a ele, na medida em que o critério para a sua concretização não depende da apuração perfeita da recomposição danosa, pois se volta ao comportamento colaborativo das partes para o alcance da satisfação do interesse da vítima, cuja régua pode não equivaler à exata medida da extensão do dano.

${ }^{38}$ Para além dos critérios de eficiência, celeridade e segurança, traduz-se em comportamento cooperativo que homenageia a boa-fé objetiva. Todos esses são fatores de concretização do princípio da solidariedade.

${ }^{39}$ KELSEN, Hans. Teoria pura do direito, cit., p. 237.

${ }^{40} \mathrm{Na}$ filosofia moral, IMMANUEL KANT ressalta que a "vontade absolutamente boa" é apenas aquela formal, que atua "enquanto autonomia; isto é, a aptidão da máxima de toda boa vontade a se tornar um alei
} 
ainda que se utilizem de uma ponte oferecida pela ordem jurídica (nudge) para convencer-se acerca da tomada de decisão. ${ }^{41}$ É que, como já se defendeu, a eficácia do direito tem significado normativo: se uma pessoa age conforme o direito, a norma é eficaz, ainda que o móvel subjetivo daquele agente não guarde relação com a estrutura de sanções oferecidas (positivas ou negativas). ${ }^{42}$ Assim, serão espontâneos todos os atos de composição extrajudicial, como também aqueles que se deram no curso do processo, pelo caminho das oportunidades oferecidas na legislação processual. A contrario sensu, o comportamento não será espontâneo, tão somente, quando a pessoa é compelida, coercitivamente, a realizá-lo, como por exemplo, pela via de decisão judicial, ou de protesto de título, ou de execução forçada extrajudicial, etc.

Outra objeção de extrema relevância é aquela que pode invocar suposta contradição entre a ideia de reparação espontânea dos danos e a utilização da transação como um dos mecanismos de direito material essencial à concretização da função promocional da responsabilidade civil. ${ }^{43}$ Em outras palavras, pode traduzir-se em sofisma a consideração de que a transação é meio de reparação dos danos. ${ }^{44}$ De fato, em termos dogmáticos, a composição negocial do litígio não pode ser interpretada como equivalente à reparação de danos. É instrumento, de direito material, cuja função é auxiliar, na responsabilidade civil, a vítima de danos sofridos a alcançar a satisfação de seu interesse, mediante concessões recíprocas. Logo, também não pode corresponder à ideia de reparação ou compensação integral dos danos. Esta representa a exata medida (extensão) da lesão experimentada (art. 944, caput, do Código Civil). ${ }^{45} \mathrm{~A}$ transação corresponde a instrumento negocial por via do qual os interessados buscam evitar ou pôr termo a litígio, mediante concessões mútuas (art. 840 do Código Civil). ${ }^{46-47}$ Logo, são situações jurídicas distintas.

universal" (Fundamentação da metafísica dos costumes. Trad. Guido Antônio de Almeida. São Paulo: Barcarola, 2009, p. 301), no sentido de que apenas o comportamento que cumpre o dever proveniente da razão é aquele "bom comportamento". Aqui não se restringe o móvel subjetivo a este espectro, podendo mesmo tratar-se de atuação espontânea influenciada por fontes heterônomas, ou mesmo senso meramente intuito ou benevolente (não-racional).

${ }^{41}$ Dedica-se ao estudo dos "incentivos" para a prática das boas condutas sociais a escola behaviorista do direito. Por todos, cf. ALEMANNO, Alberto; SIBONY, Anne-Lise. Nudge and the law: a european perspective. London: Bloomsbury, 2015.

${ }^{42}$ KELSEN, Hans. Teoria pura do direito, cit., p. 28.

${ }^{43}$ Como é cediço, a transação é o negócio jurídico, de direito material, que se busca alcançar pelos meios processuais da conciliação e da mediação, supra referenciados, cujo espoco é a prevenção ou o término do litígio, mediante concessões mútuas (art. 840 do Código Civil). A aludida autocomposição é formatada por via da transação. Neste sentido, afirma FRANCISCO CAVALCANTI PONTES DE MIRANDA que "ainda quando feitas em juízo, as transações regem-se pelo direito material" (Tratado de direito privado. v. 25. Rio de Janeiro, Borsoi, 1971, p. 142).

${ }^{44}$ Evidentemente, não poderia um contrato representar uma modalidade de extinção da obrigação. Extinção de relação jurídica é efeito (situação jurídica extintiva), sendo o contrato, quando muito, o título que integra a causa da extinção. Acerca da distinção entre causa, título e efeito (situação jurídica subjetiva), Cf. PERLINGIERI, Pietro. O direito civil na legalidade constitucional, cit., pp. 737-740.

45 "Art. 944. A indenização mede-se pela extensão do dano".

46 "Art. 840. É lícito aos interessados prevenirem ou terminarem o litígio mediante concessões mútuas".

${ }^{47}$ A propósito, desta ORLANDO GOMES ser "necessário que haja concessões mútuas, de qualquer teor", pois "concessões feitas somente por um dos interessados implicam renúncia ou reconhecimento do direito do outro". E segue: "tudo conceder sem nada receber não é transigir" (Contratos. 26. ed. Rio de Janeiro: Forense, 2007, p. 544). 
A transação é acordo de vontades que tem por finalidade evitar ou extinguir um litígio, ${ }^{48}$ tornando-se natural que os interessados formem o consentimento considerando a redução recíproca da posição jurídica atual de cada um. ${ }^{49} \mathrm{~A}$ sua função é garantir a paz e a harmonia entre as partes, que rejeitam a sua manutenção em zona de litígio, eliminando a incerteza da relação jurídica e certificando-se de que a controvérsia será prontamente solucionada, por via de instrumento negocial juridicamente seguro. ${ }^{50}$ Ambos têm pressa em resolver a disputa, sendo o interesse pela celeridade uma característica imanente da transação. O devedor se prontifica a solver imediatamente o débito acordado, para que a situação não prolongue no tempo, causando-lhe prejuízos maiores. $O$ credor aceita o pagamento célere da prestação definida no acordo, sabendo que provavelmente não corresponderá à exata medida do dano (reparação integral), mas ciente de que Ihe causará maior satisfação, pela rápida composição. Os interesses da vítima encerram complexidade que não pode se restringir ao desejo da recomposição exata do prejuízo ou da compensação equivalente da lesão sofrida.

No instrumento transacional, portanto, os interessados podem (i) criar nova obrigação ao agente causador do dano, para extinguir ou substituir a anterior, formatando-se uma novação objetiva (art. 360, I do Código Civil); ou, sem necessariamente novar a obrigação de indenizar, podem também (ii) acordar pela redução do quantum indenizatório, mediante pronto pagamento, ou com vencimento de curto prazo; (iii) estipular que a vítima aceita receber prestação diversa da que the é devida, imediatamente ou em tempo exíguo, como forma de dação em pagamento (art. 356 do Código Civil), assim como acordar outros arranjos semelhantes. ${ }^{51}$

É negócio jurídico bilateral e de forma necessariamente escrita (escritura pública ou instrumento particular). ${ }^{52}$ É também negócio consensual, ${ }^{53}$ ainda que o exercício da autonomia

\footnotetext{
48 "La transazione infime è il contratto con il quale le parti pongono fine a una lite già cominciata o prevengono una lite che sta per sorgere tra loro, facendosi reciproche concessioni" (TRABUCCHI, Alberto. Istituzioni di diritto civile. 47. ed. Padova: CEDAM, 2015, p. 1089).

${ }^{49}$ A reciprocidade de concessões é elemento essencial da transação, residindo daí o seu caráter constitutivo, como defende MESSINEO, Francesco. Manuale di diritto civile. v. 3. Milano: Giuffrè, 1947, p. 236.

${ }^{50}$ A eliminação das incertezas é a finalidade nodal do instituto, identificada por ENNECCERUS, Ludwig; KIPP, Theodor; WOLFF, Martin. Tratado de derecho civil. Tomo 2. v. 2. Barcelona: Bosch Publicaciones Jurídicas, 1948, p. 495. No mesmo sentido, SANTORO-PASSARELI, Francesco. La transazione. 2. ed. Napoli: Jovene, 1963, v. 1, p. 12. Destaca-se, aliás, que a intenção de eliminar as incertezas não precisa se calcar em fato objetivamente incerto, bastando a que haja incerteza do ponto de vista subjetivo (ENNECCERUS, Ludwig; KIPP, Theodor; WOLFF, Martin. Tratado de derecho civil, cit., p. 496).

${ }^{51}$ A transação já foi considerada como modalidade de extinção das obrigações, mas tal concepção restritiva já foi há muito superada pela sua qualificação como contrato, de caráter constitutivo, capaz de criar relações jurídicas, "eficácia que não se teria de fora o negócio simplesmente declaratório" (GOMES, Orlando. Contratos, cit., p. 543).

${ }^{52}$ Art. 842. A transação far-se-á por escritura pública, nas obrigações em que a lei o exige, ou por instrumento particular, nas em que ela o admite; se recair sobre direitos contestados em juízo, será feita por escritura pública, ou por termo nos autos, assinado pelos transigentes e homologado pelo juiz.

${ }^{53}$ Não é possível realizar transação como negócio jurídico real, isto é, efetivamente, por meio dela, atos materiais como pagamento ou transmissão de direitos. Tudo o que nela constar terá efeito declaratório, como o reconhecimento da obrigação a cargo do devedor, que se obriga por meio dela. O pagamento, assim, reveste como cumprimento da prestação nela imposta, e não como ato material constitutivo da
} 
seja limitado pela lei aos atos de caráter privado e de natureza patrimonial, ${ }^{54}$ devendo-se, enfim, interpretá-lo restritivamente. ${ }^{55}$ Não gera efeitos perante terceiros desinteressados, ${ }^{56}$ mas se admite a imposição de pena convencional, como medida coercitiva para o seu cumprimento. ${ }^{57}$

Postas em relevo as características fundamentais do negócio jurídico, volta-se à questão apresentada acima, acerca da possibilidade de ser a transação instrumento para o alcance da reparação espontânea do dano.

Com efeito, é inequívoco o fato de não servir a transação como modalidade de extinção da obrigação de indenizar. Não seria correto afirmar que a transação é modo de pagamento, relacionado à obrigação de indenizar proveniente do dano causado na esfera extracontratual. ${ }^{58}$ Contudo, não há contradição ao indicar a transação como um dos meios relevantes para a concretização da função promocional da responsabilidade civil. É que, como já se acentuou, a novel função persegue um modelo instrumental de fomento à reparação espontânea do dano, pela via das chamadas sanções positivas: se agires do modo desejado, terás um determinado benefício, alçando uma posição jurídica necessariamente mais favorável que a anterior.

Portanto, sendo a função promocional uma finalidade voltada ao controle de comportamentos, não se vincula ela ao cumprimento da obrigação de indenizar de forma integral, orientada à recomposição perfeccionista da lesão. A reparação integral é componente da função reparatória-compensatória. O estímulo a condutas desejadas, ainda que não se alcance a totalidade da finalidade primária (função reparatória-compensatória), voltando os olhos ao bom comportamento humano e inter-relacional, é o ingrediente que compõe a função promocional da responsabilidade civil. ${ }^{59}$

transação. Neste sentido, o art. 843 do Código Civil: "A transação interpreta-se restritivamente, e por ela não se transmitem, apenas se declaram ou reconhecem direitos" (grifos nossos).

${ }^{54}$ Art. 841 . Só quanto a direitos patrimoniais de caráter privado se permite a transação.

${ }^{55}$ Art. 843. A transação interpreta-se restritivamente, e por ela não se transmitem, apenas se declaram ou reconhecem direitos.

${ }^{56}$ Art. 844. A transação não aproveita, nem prejudica senão aos que nela intervierem, ainda que diga respeito a coisa indivisível.

$\S 1^{\circ}$. Se for concluída entre o credor e o devedor, desobrigará o fiador.

$\S 2^{\circ}$. Se entre um dos credores solidários e o devedor, extingue a obrigação deste para com os outros credores.

$\S 3^{\circ}$. Se entre um dos devedores solidários e seu credor, extingue a dívida em relação aos co-devedores".

57 "Art. 847. É admissível, na transação, a pena convencional.

${ }^{58}$ A propósito, a transação era definida pelo Código Civil de 1916 como forma de adimplemento. Descreve CLóVIS BEVILAQUA que a transação "é um acto jurídico pelo qual as partes, fazendo-se concessões recíprocas, extinguem ou previnem litígios (...). Não é a transacção um simples contracto, embora contenha os elementos constitutivos dessa espécie de actos jurídicos (...). Mas, por seu objecto, por seu fim, a transacção é, realmente, um modo de extinguir obrigações" (Direito das obrigações. 5. ed. Rio de Janeiro: Freitas Bastos, 1940, p. 134). Entretanto, tal qualificação abstrata já foi bastante criticada pela doutrina, dada a sua natureza contratual (GOMES, Orlando. Contratos, cit., p. 543). Logo, a transação pode até importar em extinção da obrigação anterior, mas esta será mero efeito do contrato e não ela mesma uma forma de pagamento, como bem reconheceu o Código Civil de 2002.

${ }^{59}$ Eis aqui o marco que define a autonomia entre a função reparatória e a função promocional, não sendo esta mera parte integrante daquela. Não se trata, pois, a função promocional, de uma função da função. Na perseguição do sentido ético da finalidade última do direito dos danos, o ordenamento prevê que mesmo a possibilidade de superação da ideia central originária da reparação integral, por outra ético-comportamental, 
Dessa arte, é possível que determinado agente concretize a função reparatóriacompensatória, sem dar cabo à função promocional, como sói ocorrer na quase totalidade das situações atuais. Por outro lado, é possível que a vítima se satisfaça sem que se realize a função reparatória-compensatória, em sua integralidade (ou a realize de modo parcial), porque ela decidiu, em conjunto com o agente causador do dano, seguir os estímulos da função promocional. ${ }^{60}$ Exatamente por isso, é razoável que um dos benefícios possíveis da atuação conforme o valor da autocomposição seja a desnecessidade de cumprir com a reparação integral, desde que tenha realizado uma prestação que seja equivalente ao que seria uma reparação suficiente (e eficiente), satisfazendo plenamente o interesse do credor (vítima). ${ }^{61}$

$\mathrm{Na}$ função promocional, a integralidade ou plenitude que deve ser buscada é da realização do interesse subjetivo da vítima, para uma reparação que preencha suficientemente o vácuo causado pelo dano, já não a recomposição perfeita do dano. ${ }^{62}$ Pelo lado do agente, busca-

de autocomposição, que já não visa a restituição ao status quo ante, mas, simplesmente, a uma forma alternativa, eficaz, célere e humana (inter-relacional) de satisfação do interesse da vítima no pós-dano.

${ }^{60}$ É importante destacar que a função promocional, como escopo ligado à finalidade última da responsabilidade civil, ainda que se concentre no perfil ético-comportamental das partes, pressupõe o dano e dele não se desliga, o que implica reconhecer ser ela ancorada na finalidade primária, que também orienta a função reparatória-compensatória. Contudo, por focarem em aspectos distintos, ainda que paralelos, de satisfação do interesse da vítima (seara comportamental, de um lado, e de recomposição objetiva das perdas, de outro), se é bem verdade que a realização da função promocional não garante a plena realização da função reparatória-compensatória, pela não vinculação à regra da reparação integral, não se pode negar que a concretização do perfil promocional da responsabilidade civil, pelo estímulo à reparação espontânea do dano, sempre atenderá à finalidade primária em alguma medida. Inconcebível, por exemplo, que na transação a vítima abra mão de toda e qualquer forma mitigada ou alternativa de compensação, pois já não se trataria de transação, mas de renúncia do direito à indenização. Decerto que nada impede à vítima renunciar a seu direito à indenização, por não haver impedimento algum neste sentido (CAVALCANTI, José Paulo. Da renúncia no direito brasileiro. Rio de Janeiro: Forense, 1958, p. 108), constituindo-se como "perda voluntária de um direito mediante declaração unilateral de seu titular" (ALMEIDA COSTA, Mário Júlio de. Direito das obrigações. 12. ed. Coimbra: Almedina, 2011, p. 1115), mas tal ato unilateral não é estimulado pela função promocional.

${ }_{61}$ Fala-se em reparação suficiente como aquela que é capaz de ocupar, de alguma forma, o vazio deixado pela lesão, substituindo, satisfatoriamente, o conteúdo do interesse violado (patrimonial ou existencial). Esse juízo de suficiência é subjetivo e, por essa razão, só pode ser realizado pela própria vítima, pela via da transação, nunca por terceiros ou pelo juiz. Por sua vez, a eficiência é mais um valor do ordenamento que se mostra mais apto à realização na função promocional que no âmbito judicial da função reparatóriacompensatória. A reparação espontânea do dano, quando extrajudicial, é evidentemente mais eficiente que aquela imposta pela resolução de uma lide judicial. Mesmo a autocomposição judicial ganha em eficiência, porque poupa os atos processuais subsequentes que são obrigatórios para a prolação da sentença (devido processo legal). Quer-se dizer que a transação exala eficiência naturalmente superior à resolução judicial das controvérsias, no sentido de que os benefícios alcançados por ambas as partes foram atingidos, necessariamente, com menores custos, em comparação àqueles que seriam obtidos na relação jurídica processual. Neste quesito, essa perspectiva econômica do direito é uma visão que agrega a realização dos valores civis-constitucionais. Como ainda se mencionará, a eficácia é outro valor que é concretizado na transação, desde que o objetivo seja alcançado de modo seguro, em negócio firmado sem vícios. Daí apresentar, ao remate, a necessidade de buscar, à guisa de completude, a máxima efetividade dos valores que norteiam a responsabilidade civil, especialmente aqueles de natureza constitucional, no sentido de propor instrumentos suficientes a alcançar a maior eficácia possível (Cf. SARLET, Ingo Wolfgang. A eficácia dos direitos fundamentais. 12. ed. Porto Alegre: Livraria do Advogado, 2015, passim).

${ }^{62}$ Substitui-se o perfeccionismo e a infalibilidade da aritmética da função reparatória-compensatória por uma ética comportamental de composição dos interesses em litígio, como concretização do princípio da solidariedade. Afinal, já afirmava MAURICE BLONDEL que "La responsabilité est la solidarité de la personne humaine avec ses actes, condition préalable de toute obligation" (Vocabulaire technique et critique de la philosophie. Paris: PUF, 1947, p. 907). Como lembra GENEVIEVE VINEY, se a evolução da responsabilidade civil levou à admissão de objetivos até mesmo distintos da reparação (l'evolution des idées sur la 
se o agir conforme o direito em sua máxima efetividade. Se aquele que causou o dano extracontratual deve repará-lo, estando em mora desde o instante em que o praticou (art. 398 do Código Civil), que seja purgada prontamente, beneficiando-se, também, o ofensor, por sua conduta louvável. ${ }^{63}$

llustrativamente, se João, numa situação de trânsito de veículos, atinge, culposamente, o automóvel de Maria, causando-lhe prejuízos de ordem patrimonial e extrapatrimonial (lesões corporais), poderá ser ele condenado a indenizar Maria. Em tese, para que ele se exonere deste dever, faz-se necessário o pagamento de todas as despesas pelo desfalque patrimonial imediato, verificado pelos danos causados ao veículo, como também os custos do tratamento de Maria, além daquilo que ela comprovadamente deixou de receber em seu trabalho, com espeque no art. 949 do Código Civil, reunindo danos emergentes e lucros cessantes, na perspectiva dos danos patrimoniais. Ademais, é possível também que seja ele obrigado a indenizar o dano extrapatrimonial causado pela lesão corporal sofrida por Maria, podendo até mesmo ser verificada a ocorrência de danos estéticos.

Nesta situação, a posição jurídica de João é de considerável incerteza. Primeiro, não sabe se será condenado. É preciso que haja uma ação e que o juízo se convença acerca da narrativa fática e dos fundamentos jurídicos do pedido do autor, com base no acervo probatório produzido nos autos. Neste balanço, não se pode desconsiderar o peso do exercício do direito de defesa, que será tão maior quanto mais convicto o réu estiver de sua inocência, em conjunto com o que puder produzir de prova a seu favor. Caso sejam frágeis seus argumentos de defesa ou a prova que pretende produzir (ou mesmo a ausência dela), maior será a convicção de João acerca de sua condenação. Ainda assim, permanecerá acesa a chama da incerteza, não apenas em torno da própria condenação (ainda que provável), mas também sobre o que será condenado (se apenas à indenização dos danos materiais ou, também, de danos morais, ou, ainda, se serão acrescidos valores a título de indenização de danos estéticos), ${ }^{64}$ e o sobre o quanto será obrigado a pagar, condenação esta certamente imposta na modalidade pecuniária (porque assim foi o pedido específico da parte autora/vítima). ${ }^{65}$

A eliminação desse conjunto de incertezas em torno do litígio é o primeiro móvel

responsabilité civile a fait apparaître d'autres perspectives qui conduisent à assigner également à cette institution des objectifs nettement distincts de la réparation, même entendue le plus largement possible), maior razão haverá em reconhecer objetivos a ela conectados (Traité de droit civil: la responsabilité - effets, Paris : LGDJ, 1988, p. 4).

${ }^{63}$ Se é certo que a prevenção do dano é a função cronologicamente prioritária, também é verdade que, numa concepção realista do direito, nem mesmo a sociedade mais bem ordenada será capaz de evitar certos danos, o que não implica sacrificar, de plano, o agente causador, quando se pode oferecer a ele a alternativa da redenção. Deste modo, caso busque, prontamente, compensar a vítima do modo mais eficiente possível, realizando integralmente o seu interesse (que não se confunde com o aritmético princípio da reparação integral), tendo na transação um dos instrumentos propícios a tal desiderato, deve gozar de certos benefícios que não teria se inerte se mantivesse. Sobre que tipo de benefícios seriam esses, cf. infra. ${ }^{64}$ Sabe-se que, jurisprudencialmente, há entendimento consolidado no sentido de que "é lícita a cumulação das indenizações de dano estético e dano moral" (Súmula n. 387 do Superior Tribunal de Justiça).

${ }^{65}$ Como já aqui acentuado, não se coaduna do entendimento segundo o qual "a indenização é compensatória (...), sendo representada sempre por um valor em dinheiro, denominado id quod interest" (WALD, Arnoldo. Direito civil. São Paulo: Saraiva, 2015, v. 2, p. 175). 
que serve de estímulo natural (interno) para que as partes envolvidas prefiram compor os seus interesses, ${ }^{66}$ reduzindo reciprocamente as suas posições jurídicas ao ponto de confluência suficiente para a satisfação mútua. Para o ordenamento jurídico, como foi salientado, a transação também ocupa posição preferencial na ordem de valores, seguindo uma tendência hodierna de desjudicialização dos litígios e realização concreta do ideal de harmonização e pacificação social. Contudo, a experiência demonstra que tais fatores não são suficientes para o alcance de um número expressivo e razoavelmente esperado de autocomposição. É necessário o "empurrão" do Estado (nudge), para que os interessados, livremente, sintam-se verdadeiramente estimulados para realizar o valor que a ordem jurídica e social, considerada globalmente, tanto espera. ${ }^{67}$ Aqui entra o estímulo externo à autocomposição: a formatação de arcabouço legislativo, com normas de direito material e processual, que criam ambiente propício à transação, sendo este um ingrediente de estímulo normativo. ${ }^{68}$ É o espaço de atuação da função promocional da responsabilidade civil. A transação é o instrumento mais utilizado ao cumprimento da função promocional, ainda que as partes a realizem de modo inconsciente. Mas não é a única forma.

Não se pode olvidar a possibilidade de cumprimento da função promocional sem que o agente causador do dano opte pela via da transação. Nada impede que ele, simplesmente, renuncie a qualquer benefício que poderia extrair da autocomposição, preferindo se colocar à disposição para a pronta reparação integral da vítima, de forma espontânea e extrajudicial. Se já estabelecida a relação jurídica processual, não há óbice, na mesma linha, que a parte ré reconheça a procedência do pedido da parte demandante. Para este caso, há solução processual prevista no art. 487, III, "a" do Código de Processo Civil, segundo o qual o juiz deve homologar "o reconhecimento da procedência do pedido formulado na ação ou na reconvenção", extinguindo o processo, com resolução do mérito (art. 487, caput, do Código de Processo Civil).

$\mathrm{Na}$ primeira hipótese, entretanto, ante ato espontâneo do agente em reparar/compensar integralmente o dano, realizando o pagamento voluntário, pela via do aceite, por exemplo, da oferta da vítima sobre os valores a serem pagos, ou prestações (de dar, fazer ou não fazer) a serem cumpridas, é prudente que as partes firmem um termo, por escrito, com a

\footnotetext{
${ }^{66}$ PEREIRA, Caio Mário da Silva. Instituições de Direito Civil. 11. ed. Rio de Janeiro: Forense, 2003, v. 3, pp. 507-508.

${ }^{67}$ É essa composição entre intervencionismo estatal, apenas no ponto de partida, com o apreço pela liberdade de escolha dos cidadãos, que se tem denominado de "paternalismo libertário". Veja-se, por todos, SUNSTEIN, Cass S.; THALER, Richard H. Libertarian Paternalism Is Not an Oxymoron, cit., passim.

${ }_{68}$ Acrescente-se a isso, ainda, as medidas da administração judiciária, de cunho executivo, como a organização das "Semanas de Conciliação", supervisionadas pelo Conselho Nacional de Justiça (Cf. http://www.cnj.jus.br/programas-e-acoes/conciliacao-e-mediacao-portal-da-conciliacao/semana-nacional-deconciliacao), bem como os programas da "Justiça Itinerante", organizados pela Administração judiciária de cada Estado da Federação. No Estado do Rio de Janeiro, por exemplo, o Programa Justiça Itinerante "tem por objetivos precípuos dar concreção ao postulado do amplo acesso à Justiça e fomentar a cidadania, por meio de atendimentos regulares previamente estabelecidos mediante calendários amplamente divulgados", incluindo objetivo específico "buscar soluções conciliadas como fórmula de pacificação social eficiente" (grifos nossos). Cf. http://www.tjr.jus.br/web/portal-conhecimento/tj-sociedade/justicaitinerante?inheritRedirect=true.
} 
consequente emissão de quitação de dívida. ${ }^{69} \mathrm{O}$ instrumento deve servir de meio de defesa (prova de fato extintivo do direito, pelo pagamento), contra eventual ação imoral da vítima pleiteando novos valores, violando a regra da reparação integral, eis que objetiva exceder a exata medida da extensão do dano já reparado (art. 944, caput, do Código Civil). Nada impede, inclusive, que se ajuste nesta minuta a renúncia ao direito de ação por parte da vítima, ainda que neste caso o acordo se aproxime novamente da ideia de transação. ${ }^{70}$ É inegável, contudo, que mesmo um termo firmado entre as partes, neste sentido, não garante que será ele integralmente válido, a depender das condições nas quais ele foi obtido, bem como a qualidade das partes. ${ }^{71}$ Mas, como se verá, mesmo nestes casos, é possível ainda se vislumbrar um benefício que, na pior das hipóteses, deve servir, ao menos, para deduzir o valor da indenização originalmente devida.

A propósito, já é tempo de lançar o primeiro desafio para o aperfeiçoamento da função promocional da responsabilidade civil. Se esta se revela como expressão da finalidade última do sistema, de maneira a estimular a reparação espontânea dos danos, será ela realizada em maior medida (i) quanto mais próxima do evento (celeridade razoável) $;^{72}$ e (ii) quanto mais se aproximar da reparação integral (exata medida da extensão do dano), uma das características mais marcantes da finalidade primária da responsabilidade civil, representada pela função reparatória-compensatória dos danos. Neste caso, há uma confluência funcional entre a medida reparatória integral (função reparatória clássica) e a sua realização espontânea (função promocional), porque o agente se prontifica a reparar integral, voluntária e imediatamente o dano causado, sem que exija da vítima concessões mútuas para a resolução imediata da controvérsia (transação). Neste caso, o termo firmado entre as partes, no qual o agente renuncia qualquer vantagem, reconhecendo o pleito integral da vítima, deveria representar acordo ainda mais seguro e difícil de ser contestado que a avença firmada pela via da transação. É que representa síntese de interesses com merecimento de tutela ainda mais abrangente que a própria transação.

Daí se percebe que a função promocional representa, em última análise, a

\footnotetext{
${ }^{69}$ Código Civil. Art. 319. O devedor que paga tem direito a quitação regular, e pode reter o pagamento, enquanto não lhe seja dada.

${ }^{70}$ De fato, a renúncia ao direito de ação por parte da vítima deve ser qualificada como uma concessão que ela faz ao devedor, que também cede, mutuamente, ao reconhecer, sem contestar, o valor da indenização apresentado pela vítima. Em havendo "reciprocidade das concessões", efetiva-se o contrato de transação (LÔBO, Paulo. Direito civil: contratos. São Paulo: Saraiva, 2012, p. 443). Haverá outro ato jurídico se ocorrem, isoladamente, o reconhecimento do direito do outro, sem contrapartida, ou apenas a renúncia do próprio direito, sem concessão mútua. Com ambos, qualifica-se a transação.

${ }_{71}$ Cf. capítulo 4.3, infra.

${ }^{72}$ A celeridade, neste caso, deve ser interpretada em conformidade com o princípio da razoabilidade, verificando-se, no caso concreto, hipóteses em que a própria vítima só consegue diagnosticar e quantificar as suas perdas (patrimoniais e extrapatrimoniais) após o transcurso do tempo. É o melhor interesse da vítima que deve guiar o valor da celeridade, que exprime uma ideia de "duração razoável" do itinerário da reparação, não sendo necessariamente uma celeridade objetiva (art. $5^{\circ}$, LXXVIII da CF). Esta, por vezes, pode levar a tomada de decisão precipitada da vítima e do próprio agente, deixando pontos em aberto que podem gerar controvérsias futuras. A função promocional rejeita uma reparação espontânea apressada e forçada, que ao invés de pôr termo à lide, apenas a difere no tempo.
} 
concretização do princípio da máxima efetividade ao sistema de proteção à vítima conferido pela responsabilidade civil contemporânea. ${ }^{73}$ Toda vez que se fala de máxima efetividade, quer-se afirmar que é possível formatar um arranjo normativo que realize, no grau mais alto de eficácia, os princípios que norteiam determinado instituto. Na função promocional da responsabilidade civil, para além do respeito aos seus princípios e regras mais característicos, está ela a realizar os contornos axiológicos mais abrangentes, delineados pela Constituição da República, notadamente os valores da solidariedade, celeridade, eficácia, eficiência e do bem-estar social. ${ }^{74}$

\section{APLICAÇÕES DA FUNÇÃo PROMOCIONAL NA TUTELA DOS DIREITOS METAINDIVIDUAIS}

Em 22 de março de 2011, o canal MTV veiculou programa humorístico "Comédia TV", apresentando novo quadro chamado "Casa dos Autistas", cuja ideia central era satirizar a famosa atração de entretenimento "Casa dos Artistas", de emissora concorrente. Para instrumentalizar a sátira, os humoristas acabaram por valer-se de imitações espalhafatosas e galhofas - naturais no humor - não para formar caricatura dos protagonistas do programa satirizado, de acordo com suas características pessoais, mas com inserção de excessos comunicativos ao tratar os protagonistas como se autistas fossem. Logo, não só reproduziram imitação tosca dos personagens, como sói ocorrer normalmente nas atuações humorísticas. Representaram, em verdade, de forma satírica, as pessoas com autismo, por via de gestos e sons bastante exagerados. Ao fim e ao cabo, a impressão generalizada que se passou é que a chacota não era dirigida ao programa concorrente, mas diretamente às pessoas caracterizadas por aquela condição neurológica. ${ }^{75}$

Em tempos de internet, a velocidade da comunicação e o alcance que cada signo

\footnotetext{
${ }^{73}$ Nas palavras de MARIA CELINA BODIN DE MORAES, "a responsabilidade civil hoje é o principal instrumento com que conta o ordenamento para garantir efetividade aos interesses existenciais, sendo 0 principal remédio adotado para enfrentar a violação da maior parte deles" (A prescrição e o problema da efetividade do direito. A juízo do tempo. BODIN DE MORAES, M. C.; et al. (coord.). Rio de Janeiro: Processo, 2019, p. 14).

${ }^{74}$ Os valores da solidariedade e do bem-estar social estão previstos como objetivos da república, no art. $3^{\circ}$, incisos I e IV da Constituição da República: "Constituem objetivos fundamentais da República: I - construir uma sociedade justa, livre e solidária; (...) IV - promover o bem de todos (...). Note-se que o conceito de bem extraído do art. $3^{\circ}$, IV é axiológico, distinto daquele de natureza utilitarista (BENTHAM, Jeremy. An introduction to the principles of morals and legislation [1781]. Kitchner: Batoche Books, 2000, passim). Por sua vez, os princípios da celeridade e da eficácia e eficiência estão previstos, respectivamente, no art. $5^{\circ}$, LXXVIII: "a todos, no âmbito judicial e administrativo, são assegurados a razoável duração do processo e os meios que garantam a celeridade de sua tramitação" e art. $5^{\circ}, \S 1^{\circ}$ : "As normas definidoras dos direitos e garantias fundamentais têm aplicação imediata".

${ }^{75}$ Essa foi a manifestação formal da Associação Brasileira para Ação por Direitos das Pessoas com Autismo (Abraça), afirmando que "As imagens exibidas causaram dor e revolta em familiares de pessoas autistas e nelas mesmas. Serem retratados como pessoas sem sentimento, sem habilidades, sem capacidade alguma de compreensão da realidade já é corriqueiro para nossos amigos e filhos autistas, mas fazer uso de imagens preconceituosas, apresentando-os gritando e babando só vem reforçar os estereótipos muito distantes da realidade". Disponível em: http://abraca.autismobrasil.org/humoristico-damtv-desrespeita-pessoas-autistas/. Acesso em 02.11.2018.
} 
comunicativo pode atingir é incomensurável. Neste caso, houve ampla divulgação da peça humorística e a reação da sociedade civil foi imediata, com diversas manifestações públicas de repúdio. Em resposta, o próprio humorista produziu pedido formal de desculpas. ${ }^{76}$ Concomitantemente, a emissora passou a atuar ativamente em diversos setores relevantes da sociedade, no intuito de mostrar-se apoiadora dos interesses que promovem o valor da pessoa portadora de autismo. Dentre as suas ações, destacaram-se: (i) reunião com a sociedade civil, que culminou na elaboração de carta que foi enviada à Comissão dos Direitos Humanos do Senado, dando início a planos de ação propostos por entidades que defendem a causa autista; (ii) esclarecimento dos fatos ocorridos perante o Congresso Nacional, que manifestou compreensão, assim como aprovação quanto à forma de ação proativa da Emissora após o caso, arquivando o procedimento antes instaurado em Audiência Pública; (iii) esclarecimento dos fatos perante o Ministério Público Federal, que entendeu os argumentos como convincentes, de modo a arquivar a representação instaurada; (iv) veiculação, nos intervalos comerciais de sua programação, de vinhetas institucionais sugeridas pelas entidades da sociedade civil, que tratavam do tema autismo, como forma de promover o interesse reconhecidamente violado por ela, ainda que de forma não intencional; (v) produção de 06 (seis) vídeos institucionais referentes ao assunto; e (vi) produção de um documentário veiculado no próprio Portal MTV, acerca dos debates travados após o ocorrido. ${ }^{77}$

Em paralelo, diversos pais e mães de pessoas com espectro autista ajuizaram ações individuais buscando a reparação dos danos sofridos pelos filhos e por eles mesmos, ao assistirem àquilo que qualificaram como ofensa à dignidade individual de cada um, em manifesto abuso da liberdade de expressão. Em ação movida na Comarca de São Paulo, o juízo de primeira instância condenou a Emissora ao pagamento de indenização dos danos morais causados aos pais e à criança portadora de autismo, ${ }^{78}$ em sentença reformada pelo Tribunal de Justiça de São Paulo, cujo acórdão entendeu que o programa jocoso, ainda que de mau gosto, não ofendeu, "direta e pessoalmente", os membros da família, "pois a sátira a eles não se referiu". ${ }^{79}$

76 Como se pôde acompanhar em diversas matérias jornalísticas no meio digital: http://entretenimento.r7.com/famosos-e-tv/noticias/marcelo-adnet-se-desculpa-por-fazer-piada-comautistas-na-tv-20110424.html. Acesso em 02.11.2018.

${ }^{77}$ Tais informações foram extraídas das defesas apresentadas pela Emissora nos processos aos quais figurou como ré, sendo fatos incontroversos nos autos. Ademais, a impressa também noticiou a retratação da emissora e as ações programadas para tentar "reparar" o dano causado: https://www.terra.com.br/diversao/tv/mtv-se-retrata-apos-polemica-com-quadro-casa-dosautistas,65ddc63c8b15a310VgnCLD200000bbcceb0aRCRD.html> Acesso em 02.11.2018.

${ }^{78} \mathrm{~A}$ sentença julgou procedente os pedidos contidos na ação de indenização, movida por pai, mãe e dois filhos, contra o canal de televisão, em virtude da veiculação de programa humorístico com representação jocosa de portadores de autismo, condenando a ré no pagamento de $\mathrm{R} \$ 10.000,00$, para cada um dos quatro autores, corrigidos monetariamente pela Tabela Prática do Tribunal de Justiça de São Paulo, a partir da data da sentença, acrescidos de juros de $1 \%$ ao mês desde a citação, mais custas, despesas processuais e honorários advocatícios de $15 \%$ do valor da condenação (processo n. 014350208.2011.8.26.0100).

${ }^{79} \mathrm{O}$ acórdão foi assim ementado: "RESPONSABILIDADE CIVIL. Danos Morais. Programa humorístico da MTV intitulado 'Casa dos Autistas', com representação jocosa de autistas em geral, como sátira de outro 
Em caminho inverso, pai e mãe, por si e representando filho autista, moveram ação na Comarca do Rio de Janeiro, a partir do mesmo fato e com fundamentos idênticos à demanda movida no estado vizinho, requerendo a condenação do conglomerado, sob o qual integra a emissora, ao pagamento de danos morais individualizados. Em sentença, com apoio no parecer do Ministério Público, o juízo de primeira instância julgou improcedentes os pedidos, ao argumento de que não se identificou o nexo causal entre a conduta ofensiva e os danos individuais alegados, porquanto "não houve o propósito de ofender pessoal e diretamente os autores". E acrescentou, como razão de decidir, que "a ré retirou da sua grade de programação o programa em exame e tomou providências no sentido de minimizar eventuais efeitos negativos que sua veiculação possa ter produzido no meio social", chamando atenção para o fato de que cedeu, "inclusive, espaço às associações representantes de autistas para a promoção de sua causa" ${ }^{80}$ A sentença veio em consonância com o parecer do Ministério Público. ${ }^{81}$

Nota-se, assim, que a jurisprudência já deu os primeiros passos para o reconhecimento, ainda que inconsciente, de que a responsabilidade civil persegue uma função promocional, intimamente ligada ao estímulo à reparação espontânea do dano. Neste caso, reconheceu-se que os atos executados pelo agente causador do dano ao interesse difuso de proteção à pessoa com espectro autista representaram o (i) reconhecimento espontâneo da

programa de televisão. Ação proposta por pai e mãe de autistas. Indenização reconhecida em primeiro grau. Ausência de ânimo de injuriar ou ofender, direta e pessoalmente, os autores e seus dois filhos, pois a sátira a eles não se referiu. Improcedência decretada. Recurso Provido" (TJSP. Apelação Cível n. 014350208.2011.8.26.0100, Rel. Des. Walter Barone, julgado em 15/05/2013).

${ }^{80}$ Assim foi a íntegra da sentença, extraído o relatório: "Fundamento e decido. O presente feito comporta o julgamento antecipado da lide, em consonância com o disposto no artigo 330, inciso I, do CPC, pois constam dos autos elementos suficientes para o exercício de cognição exauriente, fundada em juízo de certeza, estando a causa madura para a prolação de sentença de mérito definitiva. Não se identifica nexo de causalidade entre a veiculação do programa humorístico de cunho satírico produzido pela ré 'Casa dos Autistas' e o alegado dano, na medida em que não houve o propósito de ofender pessoal e diretamente os autores. Sem caracterizar injúria ou qualquer ofensa moral dirigida aos autores, não se localiza nenhuma responsabilidade capaz de, a título de violação de direitos da personalidade, desencadear a obrigação de Ihes serem indenizados supostos danos morais. Ademais, conforme comprovado nos autos, a ré retirou da sua grade de programação o programa em exame e tomou providências no sentido de minimizar eventuais efeitos negativos que sua veiculação possa ter produzido no meio social, cedendo inclusive espaço às associações representantes de autistas para a promoção de sua causa. Sem a individualização de alvos específicos, não é crível que o programa despertasse reações hostis ou constrangedoras por parte de terceiros, que pudessem caracterizar dano moral indenizável. Face ao exposto, resolvo o mérito, na forma do art. 269, I do CPC e JULGO IMPROCEDENTES os pedidos e condeno os autores no pagamento das custas e honorários que fixo em $10 \%$ sobre o valor atribuído à causa, verbas cuja execução suspendo porque beneficiários da assistência judiciária gratuita. P.R.I. Após o trânsito em julgado, cumpridas todas as formalidades legais, dê-se baixa e arquivem-se os autos" (TJRJ. $35^{\text {a }}$ Vara Cível da Comarca do Rio de Janeiro, Autos n. 0166276-96.2012.8.19.0001, Juíza de Direito Juliana Lamar Pereira Simão, julgado em 20/06/2014).

${ }^{81}$ Destaque para os fundamentos expostos na promoção ministerial: "Por derradeiro, segue-se que nos casos de violação a interesses difusos ou coletivos, nem sempre a reparação pecuniária é a maneira mais eficiente de compensar o dano causado, razão pela qual a doutrina tem chamado cada vez mais atenção para as formas alternativas de reparação de dano, como o direito de resposta ou a retratação voluntária do agente. Na hipótese vertente, inclusive, a ré de livre e espontânea vontade mobilizou-se para atender às demandas de alguns setores da sociedade civil, com reuniões, audiências públicas e medidas de promoção e divulgação da dignidade dos autistas, fato este que já denota a sua boa-fé e uma medida mais eficiente na promoção dos direitos das pessoas portadoras de autismo em geral' (grifos nossos). O parecer foi exarado pela $4^{a}$ Promotoria de Justiça Cível do Ministério Público do Estado do Rio de Janeiro, assinado pela promotora FLÁVIA FIGUEIREDO ROXO. 
lesão e, por conseguinte, (ii) a sua voluntária e suficiente reparação, ainda que na forma nãopecuniária. Porém, quiçá ainda mais eficiente para alcançar o nível adequado de tutela do interesse metaindividual. Por essa razão, a parte ré, além de invocar a impossibilidade de uma demanda individual por danos metaindividuais, ${ }^{82}$ suscitou, em defesa, que os danos já haviam sido plenamente reparados. A sentença de improcedência nada mais foi que um benefício, ainda que implícito, ao cumprimento da função promocional.

É necessário destacar, contudo, que ao contrário do que ocorreu no Tribunal de Justiça de São Paulo, no qual a emissora venceu a lide apenas em segunda instância, a sentença de improcedência supracitada, que fez referências expressas às características da função promocional da responsabilidade civil, foi reformada pela Sexta Câmara Cível do Tribunal de Justiça do Estado do Rio de Janeiro, que deu provimento à apelação para condenar a ré ao pagamento de $\mathrm{R} \$ 10.000,00$ (dez mil reais), para cada autor, individualmente (pai, mãe e filho portador de autismo). O fundamento se concentrou na reprovabilidade da conduta ofensora e no juízo de valor sobre os limites do humor, concluindo que a sátira "ultrapassou a barreira do aceitável mostrando-se de evidente mau gosto e, causando ofensa à honra dos autores" (sic) ${ }^{83}$ Todas as medidas louváveis adotadas pela empresa no pós-dano não foram citadas nos votos proferidos, passando, pragmaticamente, a mensagem inversa de que talvez seja desinteressante buscar a via da reparação espontânea, em face do risco de ter de reparar duas vezes (bis in idem). ${ }^{84}$

Deste caso concreto é possível extrair que o ambiente do dano ao interesse difuso ou coletivo é aquele mais propício para o exercício da função promocional. A um, porque o interesse difuso ou coletivo pode ser promovido das formas mais variadas possíveis, com elevada aptidão para os atos de natureza não patrimonial, que muitas vezes são mais eficazes e

\footnotetext{
${ }^{82}$ Sobre a temática, seja consentido remeter a REIS JUNIOR, Antonio dos; BARBOSA-FOHRMANN, Ana Paula. O discurso do ódio na internet. In: MARTINS, Guilherme Magalhães (Org.). Direito privado e internet. São Paulo: Atlas, 2014, pp. 55-56.

${ }^{83} \mathrm{O}$ voto condutor deixou de enfrentar a questão da (im)possibilidade de reparação individual de dano de natureza difusa. $\mathrm{O}$ acórdão foi assim ementado: "Apelação cível. Responsabilidade civil. Danos morais. Programa humorístico da MTV, intitulado "Casa dos Autistas". Representação irônica de autistas em geral, como sátira de outro programa televisivo. Ação, proposta por mãe e filho autista. Sentença de improcedência. Ponderação entre valores constitucionalmente, erigidos. Prevalência, na hipótese, do princípio da dignidade da pessoa humana. Nexo causal, verificado. Dano moral, configurado. Arbitramento do valor da indenização em observância aos princípios da razoabilidade e proporcionalidade. Ônus sucumbenciais, invertidos. Reforma da sentença que se impõe. Provimento do recurso" (Tribunal de Justiça do Rio de Janeiro, Apelação Cível n. 0166276-96.2012.8.19.0001, Rel. Des. Cláudia PIRES dos Santos FerREIRA, julgado em 18/03/2015). Em declaração de voto, o Des. NAGIB SLAIBI ressaltou que apesar do verbete de Súmula n. 128 do TJRJ, cujo teor indica que "imputação ofensiva, coletiva, não configura dano mora (individual)", "os termos sumulares não poderiam exercer interpretação rígida".

${ }^{84}$ Apesar desta mensagem, em verdade, a questão é que o acórdão que reformou a sentença considerou a existência de dano individual aos autores da demanda, ainda que não tenha havido ofensa direcionada, pessoalmente, aos demandantes. Neste caso, de fato, a ré em momento algum reparou espontânea e voluntariamente os danos individuais aos três autores, pessoalmente (e não havia como ter realizado tal ato de compensação espontânea, em face do desconhecimento da existência dos autores até o ajuizamento da ação). Não se desprezou, assim, os atos de reparação espontânea aos interesses difusos, apenas não era essa a questão relevante que se colocava em debate para os julgadores em segundo grau, pois tais atos visavam a recomposição dos interesses difusos violados, e não dos interesses individuais malferidos.
} 
efetivos para a reconstituição ou proteção daquele interesse que o mero depósito em fundo gerido por conselhos estaduais ou federais. ${ }^{85} \mathrm{~A}$ dois, porque há mais espaço para a reparação espontânea plena, com o reconhecimento jurídico da lesão, na medida em que um ato público de retratação, seguido de diversas ações positivas nas estruturas básicas da sociedade tem efeito ambivalente: de um lado, reparar de modo mais efetivo a lesão causada, de outro, promover a imagem do próprio agente causador, que pode reverter a impressão de ofensor de interesses públicos. A três, porque tem mais aptidão de seguir com a tendência de despatrimonialização da indenização, especialmente quando ligada a ofensa a interesses não-patrimoniais, ou daqueles que se sabem não recuperar pelo simples depósito de dinheiro na conta de certos gestores. A quatro, porque a reparação espontânea e voluntária raramente depende de uma negociação com a "parte contrária", que é naturalmente indeterminada, nos interesses difusos, e apenas determináveis, nos interesses coletivos.

\section{DESAFIOS À FUNÇÃO PROMOCIONAL NA TUTELA AMBIENTAL}

Era início da tarde de 25 de janeiro de 2019 quando mais uma barragem da mineradora Vale S/A, na região do córrego do Feijão, em Brumadinho (MG), rompeu-se sem o disparo anterior das sirenes de alerta. Como resultado, uma tragédia ambiental que deixou enorme rastro de morte e destruição. Embora a extensão do dano estritamente ambiental não tenha sido superior ao rompimento da barragem do Fundão, na região de Mariana (MG), três anos antes, a profundidade da lesão foi mais intensa, porque alcançou número maior de mortes humanas.

Em comum a ambas tragédias ambientais, o impacto de larga extensão causado (i) ao meio ambiente em si mesmo considerado (destruição da fauna, da flora, do ecossistema do Rio Doce e do Rio Paraopeba, atingindo o ecossistema marinho), (ii) ao sistema de abastecimento público de água e à infraestrutura das cidades-base (Mariana e Brumadinho); (iii) à economia local (atividade pesqueira, turismo e aos familiares e dependentes das vítimas). Outrossim, a percepção de que foram incidentes anunciados, previsíveis e prováveis, com falha notória na efetividade da função preventiva da responsabilidade civil.

De novidade apenas a reação espontânea e inédita da mineradora responsável pelo colapso da barragem em Brumadinho. Em seu primeiro pronunciamento, anunciou-se um pacote de ações que incluiu multiplicidade de medidas para mitigar os efeitos danosos, reparar as vítimas e os danos causados ao Poder Público e ao meio ambiente, abrindo-se canal de

\footnotetext{
${ }^{85}$ Dispõe o art. 13 da Lei n. 7.347/85 que "Havendo condenação em dinheiro, a indenização pelo dano causado reverterá a um fundo gerido por um Conselho Federal ou por Conselhos Estaduais de que participarão necessariamente o Ministério Público e representantes da comunidade, sendo seus recursos destinados à reconstituição dos bens lesados".
} 
comunicação com toda a sociedade local, ${ }^{86}$ sob os auspícios do Ministério Público e do Poder Judiciário.

Não obstante justas as críticas em torno atuação "atrasada" da empresa, ex post facto, que claramente inobservou os ditames da função preventiva da responsabilidade civil, e que possivelmente tenha agido por pura necessidade de preservação da imagem da empresa, a fim de salvá-la de um colapso reputacional, em nível mundial, é fato que a atuação em consonância com a função promocional da responsabilidade apresenta tons de ineditismo que merece elogios, sobretudo por tornar evidente que esta forma de agir é a nova fronteira do direito dos danos.

Não basta reparar, após longa e quase infindável batalha judicial. É imperioso que o faça de modo espontâneo e ético, a fim de alcançar o ponto máximo de eficácia e eficiência da satisfação do interesse da vítima. Esse novo "normal", alçado a patamar de new standard comportamental, traz consigo carga ética que parece traduzir o espírito dos novos tempos. Quem assim não atuar, pode sofrer severa condenação social, afetando, em última análise, a sobrevivência da empresa.

Eis a razão pela qual se reafirma que é no dano metaindividual que reside um dos espaços de maior potencial de desenvolvimento e aperfeiçoamento da função promocional. As razões, aqui, parecem ser maiores para que o agente ofensor se sinta estimulado a promover a "reparação espontânea", obtendo o ganho de imagem e outras benesses já anunciadas como prêmio por sua conduta célere, eficaz e segura.

\footnotetext{
${ }^{86}$ Dentre elas, (i) mais de 12 mil atendimentos médicos e psicológicos realizados; (ii) mais de 46 mil itens de farmácia comprados; (iii) fornecimento de alimentação, itens de higiene pessoal e primeira necessidade, medicamentos, vestuário e transporte; (iv) doação de $\mathrm{R} \$ 100$ mil para cada uma das famílias dos falecidos ou desaparecidos; (v) doação de $\mathrm{R} \$ 50$ mil para quem residia na Zona de Autossalvamento; (vi) doação de $\mathrm{R} \$ 15$ mil para quem teve negócios impactados; (vii) $R$ \$2,6 milhões repassados à Prefeitura de Brumadinho para a compra de equipamentos emergenciais e para a contratação de profissionais das áreas de saúde e psicossocial, com o objetivo de ampliar a ajuda humanitária do município aos atingidos; (viii) $\mathrm{R} \$ 6,5$ milhões investidos em equipamentos de ponta para o Instituto Médico Legal (IML) de Belo Horizonte; (ix) R\$ 270 milhões usados para aquisição de medicamentos, de água, equipamentos e outros custos logísticos; $(\mathrm{x})$ termo assinado com o Governo do Estado de Minas Gerais para apoiar a segurança das comunidades por meio de doações a serem feitas para a Defesa Civil e a Polícia Militar cujo investimento soma $\mathrm{R} \$ 9$ milhões; (xi) aporte de R\$20 milhões para o Corpo de Bombeiros Militar de Minas Gerais (CBMMG), em reconhecimento ao trabalho e heroísmo dos bombeiros militares em Brumadinho; (x) $\mathrm{O}$ acordo preliminar foi ajustado com a Advocacia Geral do Estado de Minas Gerais, o Ministério Público do Estado de Minas Gerais, a Defensoria Pública do Estado de Minas Gerais, a Advocacia-Geral da União, o Ministério Público Federal e a Defensoria Pública da União, no qual se inclui pagamento de um salário mínimo mensal para cada adulto, 1/2 (meio) salário mínimo mensal para cada adolescente e 1/4 (um quarto) de salário mínimo para cada criança pelo prazo de um ano; e pagamento de cesta básica para cada núcleo familiar das comunidades de Córrego do Feijão e Parque da Cachoeira, durante 12 meses, em valor fixado pela cesta básica do Departamento Intersindical de Estatística e Estudos Socioeconômicos (DIEESE), a ser depositado na conta corrente do responsável pelo núcleo familiar; (xi) doação de 77 veículos ao Corpo de Bombeiros, Defesa Civil, Polícia Militar e Polícia Civil de Minas Gerais; (xii) mais de 400 milhões de litros de água distribuídos para o consumo humano, animal e irrigação agrícola; (xiii) $\mathrm{R} \$ 80$ milhões em ajuda financeira para a cidade de Brumadinho; (xiv) $\mathrm{R} \$ 144$ milhões investidos em obras de contenção e reparação; (xv) $\mathrm{R} \$ 450$ milhões em obras de captação de água para garantir o abastecimento da região metropolitana de $\mathrm{BH}$; (xvi) estudos de mais 3 milhões de análises da água, solo, rejeito e sedimento ao longo da calha do Paraopeba; (xvii) mais de 1,9 bilhão de litros de água limpa devolvidos para o Rio Paraopeba; (xviii) início de investimento de $\mathrm{R} \$ 7,1$ bilhões para descaracterização de barragens, dentre outras ações.
} 
A busca pela sanção positiva (prêmio), nesta seara, tem ainda a vantagem de aproximar o agente da dureza e crueldade do dano por ele causado, o que normalmente leva o ofensor a repensar o seu comportamento preventivo. Como um círculo virtuoso, a função promocional acaba por estimular também a adoção de comportamentos futuros mais cuidadosos, elevando o status da função preventiva a nível de prioridade na atividade de risco.

Entretanto, especialmente no contexto do dano metaindividual, a ascensão da função promocional não se dá sem alguns obstáculos adicionais àqueles já enfrentados por esta nova finalidade.

O dano ambiental, que se traduz na violação a interesse ambiental socialmente protegido, impõe ao agente causador a obrigação de "reparar os danos causados", na esteira da proteção constitucional conferida pelo art. $225, \S^{\circ}{ }^{\circ}$, da CF. ${ }^{87}$ Trata-se de lesão a interesse difuso, assim entendido como aquele interesse metaindividual (ou transindividual), de natureza indivisível, de que sejam titulares pessoas indeterminadas e ligadas por circunstâncias de fato. ${ }^{88}$ Uma vez violado, é o poluidor obrigado, independentemente da existência de culpa, a indenizar ou reparar os danos causados ao meio ambiente e a terceiros, afetados por sua atividade (art. $14, \S 1^{\circ}$, da Lei $\left.n^{\circ} 6.938 / 81\right)$.

Como sói ocorrer a toda tutela coletiva, a legitimidade ativa para propor as demandas orientadas pela função reparatória-compensatória da responsabilidade civil (a perseguir uma sanção negativa) é restrita ao rol de entidades representativas do interesse juridicamente violado, previstas no art. $5^{\circ}$, da Lei n 7.347/85 (Lei da Ação Civil Pública) e no art. 82 da Lei no 8.078 (Código de Defesa do Consumidor). Atuam, pois, na posição de substitutas processuais das vítimas que foram afetadas pelo evento danoso, conforme autorizado pela parte final do art. 18 do CPC. ${ }^{89}$

Essa especificidade impõe o primeiro obstáculo adicional ao exercício da função promocional na tutela de interesses ambientais. Se a finalidade última da responsabilidade civil se orienta ao agir ético e inter-relacional, por via do qual o agente ofensor se dispõe, espontaneamente, a satisfazer o interesse da vítima, de modo eficaz e eficiente, mediante

\footnotetext{
${ }^{87}$ Consoante a jurisprudência pacífica do Superior Tribunal de Justiça, sedimentada inclusive no julgamento de recursos submetidos à sistemática dos processos representativos de controvérsia (arts. 543-C do CPC/1973 e 1.036 e 1.037 do CPC/2015), "a responsabilidade por dano ambiental é objetiva, informada pela teoria do risco integral, sendo o nexo de causalidade o fator aglutinante que permite que o risco se integre na unidade do ato" (REsp n ${ }^{\circ}$ 1.374.284/MG). De todo modo, "em que pese a responsabilidade por dano ambiental seja objetiva (e lastreada pela teoria do risco integral), faz-se imprescindível, para a configuração do dever de indenizar, a demonstração da existência de nexo de causalidade apto a vincular o resultado lesivo efetivamente verificado ao comportamento (comissivo ou omissivo) daquele a quem se repute a condição de agente causador" (Tema Repetitivo no 957, Recurso Especial $n^{\circ}$ 1596081/PR).

${ }^{88}$ Código de Defesa do Consumidor (Lei $n^{\circ}$ 8.078/90). Art. 81. A defesa dos interesses e direitos dos consumidores e das vítimas poderá ser exercida em juízo individualmente, ou a título coletivo. Parágrafo único. A defesa coletiva será exercida quando se tratar de: I - interesses ou direitos difusos, assim entendidos, para efeitos deste código, os transindividuais, de natureza indivisível, de que sejam titulares pessoas indeterminadas e ligadas por circunstâncias de fato; (...).

${ }^{89}$ Art. 18. Ninguém poderá pleitear direito alheio em nome próprio, salvo quando autorizado pelo ordenamento jurídico. Parágrafo único. Havendo substituição processual, o substituído poderá intervir como assistente litisconsorcial.
} 
instrumentos dados ao seu alcance (transação, pagamento espontâneo com confissão de dívida ou reconhecimento jurídico do pedido), assim o faz em contato, de modo cooperativo, com o ofendido. Mas o ofendido, nestes casos, é indeterminado.

Se a lesão a interesse difuso ambiental pressupõe a impossibilidade de determinar cada indivíduo que sofreu os efeitos danosos da ação poluente, impõe-se a questão de saber como e a quem deve recorrer o agente ofensor quando causar dano ambiental e tiver interesse na reparação espontânea do dano.

Nestes casos, duas situações devem ser consideradas distintas: (i) o dano ambiental causado em sentido próprio, como lesão a interesse difuso; e (ii) o dano pessoal experimentado por uma vítima determinada, em razão do acidente ambiental causado pelo agente ofensor. Naquele caso, a reparação ocorrerá nos moldes do art. 13 da Lei $n^{\circ} 7.347 / 85$, na forma de indenização a um dano moral coletivo, não havendo a possibilidade de individualização de compensação. ${ }^{90} \mathrm{Na}$ segunda hipótese, trata-se de dano individual extrapatrimonial ou patrimonial, a ser reparado por via de pretensão individual e em conformidade com a extensão do dano.

O problema inicial reside naquela primeira hipótese, em que não há vítima determinada e o interesse lesado é representado por um substituto legal. Neste contexto, tem-se observado atuação cada vez mais incisiva por parte do substituto processual, que tem capacidade para ser parte ativa na relação jurídica processual, atuando no interesse alheio (difuso ou coletivo), para representar também os interesses difusos ambientais na seara extrajudicial, notadamente no ambiente transacional. Não raro, tais acordos são homologados pelo Poder Judiciário. ${ }^{91}$

Neste caso, há um problema que parece está na origem da temática: a rigor, a transação só é permitida quanto a "direitos patrimoniais de caráter privado" (art. 841 do CC). Portanto, estariam excluídas negociações sobre a forma de recomposição in natura de interesses extrapatrimoniais, assim como os próprios interesses patrimoniais relativos à recomposição pecuniária ao fundo previsto no art. 13 da Lei $n^{\circ} 7.347 / 85$. Isso porque os interesses metaindividuais são capazes de, por si só, atraírem para si a veste de interesse público. Este é, pois, em tese, inegociável. Caberia ao Ministério Público, ilustrativamente, como

${ }^{90}$ Sobre o dano moral coletivo, Cf., por todos, CARVALHO, Luiz Gustavo Grandinetti Castanho de. Responsabilidade por dano não-patrimonial a interesse difuso (dano moral coletivo). Revista da Emerj, v. 3, n. 9, pp. 24-31, 2000; BESSA, Leonardo Roscoe. Dano moral coletivo. Revista da EMERJ, Rio da Janeiro, v. 10, n. 40, p. 247-283, 2007; RAMOS, André de Carvalho. A ação civil pública e o dano moral coletivo. Revista de Direito do Consumidor, São Paulo, n. 25, p. 82, jan/mar., 1988; MEDEIROS NETO, Xisto Tiago. Dano Moral Coletivo. São Paulo: LRT, 2004, p. 136-137; e BITTAR FILHO, Carlos Alberto. Dano moral coletivo no atual contexto brasileiro. Revista de Direito do Consumidor, São Paulo, n. 12, p. 55, out./dez., 1994; e REIS JÚNIOR, Antonio; BARBOSA-FOHRMANN, Ana Paula. O discurso do ódio na internet, cit., pp. $47-57$.

${ }_{91}$ Usualmente se tem lançado mão do instrumento do Termo de Ajustamento de Conduta (art. $5^{\circ}$, $\S 6^{\circ}$, da Lei $n^{\circ} 7.347 / 85$ ), que persegue, em tese, finalidade distinta daquela relacionada à reparação espontânea do dano metaindividual. O seu desiderato, originalmente, é direcionado ao atuar preventivo ou corretivo, ao invés de buscar o intento reparatório ou compensatório. Percebe-se, assim, redirecionamento do instituto, ampliando as suas funcionalidades a partir de categoria estrutural já prevista em lei. 
um dos entes legitimados, exigir do agente causador do dano a exata medida da compensação, mas sem importar em "concessão mútua". O interesse ambiental seria, simplesmente, indisponível. ${ }^{92}$

Por outro lado, se a "negociação" entre o agente e o substituto incidir sobre parcela de interesse individual, decorrentes do acidente ambiental, ainda assim há obstáculo difícil de ser suplantado. É que, a despeito de haver legitimidade das entidades substitutas para atuar em defesa dos interesses individuais homogêneos, a transação se traduz é fenômeno negocial que envolve concessões mútuas e pressupõe uma disposição subjetiva da parte ofendida em trocar o benefício da reparação integral por aquele da satisfação imediata de seu atual interesse. Neste caso, parece haver um problema de legitimidade dos entes substitutos para realizar esse juízo de prioridade, personalíssimo por natureza. ${ }^{93}$

Aqui se parece que tais obstáculos de natureza dogmática podem ser superados se o ambiente de negociação se dá no espaço público aberto à participação democrática da comunidade afetada pela lesão ao interesse ambiental. Um acordo firmado pelo Ministério Público e o agente causador do dano, posto ao crivo de uma audiência pública com a participação da comunidade parece capaz de superar o dogma da indisponibilidade dos direitos. É um caminho que a sistemática do direito civil-constitucional admite. Ao fim e ao cabo, busca-se a tutela mais efetiva do interesse violado.

Por outro lado, a urgência latente que emana de todo desastre ambiental exige dos entes legitimados à tutela dos interesses difusos uma atuação imediata, eficaz e efetiva para, em primeiro lugar, sustar os efeitos do dano, ou ao menos mitigá-lo, para compelir o agente a executar planos de contenção de danos; e, em segundo momento, definir o plano de ação para a recomposição da flora, da fauna e do ambiente rural ou urbano. Sendo estes os objetivos prioritários, se é possível alcançá-los pela via de acordos mais céleres firmados entre o ofensor e as entidades representativas, com os auspícios do Poder Judiciário, não há razão para rejeitálos.

A proibição da transação aos interesses indisponíveis só merece tutela quando o instrumento negocial servir-se de meio para uma concessão indevida sobre o interesse violado, pondo o direito metaindividual em situação inferior ao que estaria se fosse buscada a tutela judicial, naturalmente mais morosa. Se a judicialização do desastre ambiental pode ser mais efetiva para garantir reparações pecuniárias "integrais" (se é que se pode medir a extensão do dano em matéria de direito difuso), pode não o ser naquilo que se refere às ações de

\footnotetext{
${ }^{92} \mathrm{Em}$ sentido contrário, percebe-se alguns tratados e convenções internacionais firmados pelo Brasil que admitem a arbitragem em matéria ambiental: Convenção de Viena para a proteção da Camada de Ozônio (artigo XI, 3, a); Convenção sobre Mudança de Clima (artigo 14, 2, b); Convenção sobre Diversidade Biológica (artigo 27, a); e Convenção de Basiléia sobre o controle de movimentos transfronteiriços de resíduos perigosos e seu depósito (artigo 20,3, b). Neste ponto, Cf. por todos, ANTUNES, Paulo de Bessa. Arbitragem e meio ambiente. Revista de Arbitragem e Mediação, v. 30, p. 103-135, 2001.

${ }^{93}$ Para uma crítica abrangente, Cf. VENTURI, Elton. Transação de Direitos Indisponíveis?. Revista de Processo, v. 251, p. 391-428, 2016.
} 
recomposição in natura, muito mais relevantes para o meio ambiente que o simples aporte de dinheiro ao fundo previsto no art. 13 da Lei $n^{\circ}$ 7.347/85. Neste último caso, a eficácia e efetividade das medidas depende da execução célere e imediata de planos de ação, impossíveis de serem executados após a consolidação da destruição ambiental.

A extrema relevância da função promocional da responsabilidade civil nos danos ambientais repousa, portanto, no oferecimento de instrumentos mais eficazes e efetivos para a contenção dos danos e a sua recomposição, tratando-se de espaço mais reservado à reparação in natura e menos orientado às indenizações pecuniárias. Estas, por sua vez, podem revelar-se ótimo ingrediente de barganha nos acordos para alcançar o objetivo primordial: a defesa real do meio ambiente, por via de ações positivas, céleres e capazes de resgatar, em máxima medida, o ambiente degradado, retornando à sociedade a qualidade de vida solapada pelo evento danoso.

\section{CONCLUSÕES}

O estudo aqui apresentado procurou apresentar um panorama sistematizado da função promocional da responsabilidade civil, como modelo de estímulos a reparação espontânea do dano, em cumprimento à finalidade última do instituto. Com o foco direcionado à sua aplicação na seara da tutela dos interesses metaindividuais, sobretudo aqueles de natureza ambiental, a investigação alcançou as seguintes conclusões principais:

(i) A função promocional da responsabilidade civil é expressão da finalidade última do instituto. Aquela função que se liga às exigências comportamentais e éticas derradeiras, para que as pessoas, no exercício da solidariedade, corrijam seus equívocos espontaneamente, ainda que pela via de um estímulo. Como está ligada umbilicalmente à finalidade primária (reparatóriacompensatória), pressupõe o dano e se orienta para a sua melhor reparação ou compensação. Como está em mira o comportamento elogiável (ético) das partes envolvidas, para solver o litígio e restabelecer a harmonia social, não se prende inexoravelmente à exata medida da extensão do dano, mas ao aspecto subjetivo dos envolvidos: o agente causador quer e se comporta de maneira a compensar de forma célere, eficiente e segura; enquanto a vítima quer e se comporta de modo favorável à resolução rápida, também eficiente e de tal sorte que satisfaça o seu interesse.

(ii) Assentir com a existência de uma função promocional da responsabilidade civil pressupõe, fundamentalmente, aderir à tese de que (a) a ordem jurídica positiva visa cumprir determinadas finalidades, podendo delas extrair uma teleologia; (b) em razão disso, os institutos e categorias devem ser interpretados de maneira funcionalizada ao cumprimento de tais finalidades; (c) os mecanismos normativos, definidores dos comportamentos desejados, pela via da previsão de reação do direito diante da conduta dos sujeitos, apresentam-se de duas formas: sanções negativas e positivas; (d) a sanção positiva, definida como uma resposta benéfica do 
ordenamento a um comportamento desejável, que se faz necessário estimular, é admitida no âmbito da responsabilidade civil e extraída do contexto global do sistema; (e) os seus efeitos podem ser revelados mediante uma interpretação teleológica do direito posto, no qual já se pode vislumbrar uma aplicação prática, mesmo sem a existência de uma regulamentação específica; (f) a sua construção dogmática deve gozar de autonomia suficiente para não se confundir com as demais funções já consagradas, ainda que possa ter relação de dependência com uma delas

(iii) A função promocional representa, em última análise, a concretização do princípio da máxima efetividade ao sistema de proteção à vítima conferido pela responsabilidade civil contemporânea. Toda vez que se fala de máxima efetividade, quer-se afirmar que é possível formatar um arranjo normativo que realize, no grau mais alto de eficácia, os princípios que norteiam determinado instituto. Nela, para além do respeito aos seus princípios e regras mais característicos, está a realização dos contornos axiológicos mais abrangentes, delineados pela Constituição da República, notadamente os valores da solidariedade, celeridade, eficácia, eficiência e do bem-estar social.

(iv) Noutra perspectiva, é aquela que aperfeiçoa o sistema de proteção da vítima, conferindo mais instrumentos para o tratamento da lesão causada. Calcada na solidariedade e na esteira máxima efetividade dos direitos, busca-se, afinal, a satisfação eficaz e eficiente do interesse atual da vítima no pós-dano, que não necessariamente se confunde com a intenção única e exclusiva de recuperar ipsis litteris a situação patrimonial ou existencial de outrora. Persegue-se, ao mesmo tempo, solução célere, ainda que a busca seja por rapidez razoável, com nível de consciência e reflexão apurado entre as partes acerca da amplitude e intensidade do dano.

(v) Voltada à tutela dos interesses metaindividuais ambientais, encontra-se em locus de grande potencial de desenvolvimento. Apesar das restrições impostas ao atuar dos substitutos processuais legitimados para a tutela dos interesses das vítimas indeterminadas, tais como o problema da transação de direitos indisponíveis, apresenta-se soluções alternativas, amparadas pela sistemática civil-constitucional, como a aprovação de acordos em audiências públicas, ou simplesmente a atuação proativa para o cumprimento célere de medidas positivas de contenção e recomposição do meio ambiente em paralelo às discussões que envolvem a reparação pecuniária.

Pretendeu-se, enfim, ainda que modo tímido, contribuir para o desenvolvimento da matéria, jogando luzes sobre as vantagens da função promocional da responsabilidade civil, sem descuidar das dificuldades e desafios impostos para a sua implementação, sobretudo quando se tratar de violação a interesses difusos de natureza ambiental. 


\section{REFERÊNCIAS}

ADOLFO DI MAJO, Adolfo. Discorso generale sulla responsabilità civile. In: LIPARI, Nicolò; RESCIGNO, Pietro (Coord.). Diritto civile. Milano: Giuffrè, 2009, v. IV, t. III.

ALEMANNO, Alberto; SIBONY, Anne-Lise. Nudge and the law: a european perspective. London: Bloomsbury, 2015.

ALMEIDA COSTA, Mário Júlio de. Direito das obrigações, 12. ed. Coimbra: Almedina, 2011.

ANTUNES, Paulo de Bessa. Arbitragem e meio ambiente. Revista de Arbitragem e Mediação, São Paulo, v. 30, p. 103-135, 2001.

BARBOSA, Mafalda Miranda. Reflexões em torno da responsabilidade civil: teleologia e teleonomologia em debate. Boletim da Faculdade de Direito da Universidade de Coimbra, Coimbra: FDUC, v. 81, 2005.

BENTHAM, Jeremy. An introduction to the principles of morals and legislation [1781]. Kitchner: Batoche Books, 2000.

BESSA, Leonardo Roscoe. Dano moral coletivo. Revista da EMERJ, Rio de Janeiro, v. 10, n. 40, p. 247-283, 2007.

BEVILAQUA, Clóvis. Direito das obrigações. 5. ed. Rio de Janeiro: Freitas Bastos, 1940.

BITTAR FILHO, Carlos Alberto. Dano moral coletivo no atual contexto brasileiro. Revista de Direito do Consumidor, São Paulo, n. 12, p. 55, out./dez., 1994.

BLONDEL, Maurice. Vocabulaire technique et critique de la philosophie. Paris: PUF, 1947.

BOBBIO, Norberto. Da estrutura à função: novos estudos de teoria do direito. Tradução de Daniela Beccaccia Versiani. Barueri: Manole, 2007.

BODIN DE MORAES, Maria Celina. A caminho de um direito civil-constitucional. Revista Estado, Direito e Sociedade, v. I, p. 1-22, 1991.

BODIN DE MORAES, Maria Celina. A constitucionalização do direito civil e seus efeitos sobre a responsabilidade civil. In: Na medida da pessoa humana: estudos de direito civil-constitucional. Rio de Janeiro: Renovar, 2010.

BODIN DE MORAES, Maria Celina. A prescrição e o problema da efetividade do direito. A juízo do tempo. BODIN DE MORAES, M. C.; et. al. (coord.). Rio de Janeiro: Processo, 2019.

BODIN DE MORAES, Maria Celina. Danos à pessoa humana: uma releitura civil-constitucional dos danos morais. 2. ed. Rio de Janeiro: Processo, 2017, p. 260.

BODIN DE MORAES, Maria Celina. O princípio da solidariedade. In: Na medida da pessoa humana. Rio de Janeiro: Renovar, 2008.

BRONZE, Pinto. O Visconde de Seabra (um exercício de memória). Boletim da Faculdade de Direito, Coimbra: Ed. Coimbra, v. LXXI, 1995.

CARVALHO, Luiz Gustavo Grandinetti Castanho de. Responsabilidade por dano não-patrimonial a interesse difuso (dano moral coletivo). Revista da Emerj, Rio de Janeiro, v. 3, n. 9, pp. 24-31, 2000. 
CAVALCANTI, José Paulo. Da renúncia no direito brasileiro. Rio de Janeiro: Forense, 1958.

DUGUIT, Léon. L'état, le droit objectif et la loi positive. Paris: Albert Fontemoing, 1901.

ENNECCERUS, Ludwig; KIPP, Theodor; WOLFF, Martin. Tratado de derecho civil. Barcelona: Bosch Publicaciones Jurídicas, 1948, t. 2, v. 2.

GOMES, Orlando. Contratos. 26. ed. Rio de Janeiro: Forense, 2007.

JOSSERAND, Louis. Evolução da responsabilidade civil. Revista Forense, Rio de Janeiro, a. 38. v. $86,1941$.

KANT, Immanuel. Fundamentação da metafísica dos costumes. Tradução de Guido Antônio de Almeida. São Paulo: Barcarola, 2009.

KELSEN, Hans. Teoria pura do direito. Tradução de João Baptista Machado. 8. ed. São Paulo: Martins Fontes, 2000.

LÔBO, Paulo. Direito civil: contratos. São Paulo: Saraiva, 2012.

MEDEIROS NETO, Xisto Tiago. Dano Moral Coletivo. São Paulo: LRT, 2004.

MESSINEO, Francesco. Manuale di diritto civile. Milano: Giuffrè, 1947, v. 3.

NEVES, António Castanheira. A crise actual da filosofia do direito no contexto da crise global da filosofia: tópicos para a possibilidade de uma reflexiva reabilitação. Coimbra: Coimbra Editora, 2003.

PEREIRA, Caio Mário da Silva. Instituições de Direito Civil. 11. ed. Rio de Janeiro: Forense, 2003, v. 3.

PERLINGIERI, Pietro. O direito civil na legalidade constitucional. Tradução de Maria Cristina De Cicco. Rio de Janeiro: Renovar, 2008.

PONTES DE MIRANDA, Francisco Cavalcanti. Tratado de direito privado. Rio de Janeiro, Borsoi, 1971, v. 25.

PUGLIATTI, Salvatore. La proprietà nel nuovo diritto. Milano: Giuffrè, 1964.

RAMOS, André de Carvalho. A ação civil pública e o dano moral coletivo. Revista de Direito do Consumidor, São Paulo, n. 25, p. 82, jan./mar., 1988.

REALE, Miguel. Filosofia do direito. 12. ed. São Paulo: Saraiva, 1987.

REIS JÚNIOR, Antonio dos. Por uma função promocional da responsabilidade civil. In: SOUZA, Eduardo Nunes; SILVA, Rodrigo da Guia (Coord.). Controvérsias atuais em responsabilidade civil. São Paulo: Almedina, 2018.

REIS JUNIOR, Antonio dos; BARBOSA-FOHRMANN, Ana Paula. O discurso do ódio na internet. In: MARTINS, Guilherme Magalhães (Org.). Direito privado e internet. São Paulo: Atlas, 2014.

RODOTÀ, Stefano. II problema della responsabilità civile. Milano: Giuffrè, 1967.

RODRIGUES, Francisco Luciano Lima; VERAS, Gésio de Lima. Dimensão funcional do dano moral no direito civil contemporâneo. Civilistica.com. Revista Eletrônica de Direito Civil, Rio de Janeiro, a. 4, n. 2, 2015. 
ROSENVALD, Nelson. Funções da responsabilidade civil: a reparação e a pena civil. 3. ed. São Paulo: Saraiva, 2017.

ROSS, Alf. Direito e justiça. Tradução de Edson Bini; revisão técnica de Alysson Leandro Mascaro. 2. ed. São Paulo: Edipro, 2007.

SALLES, Raquel Bellini. A cláusula geral de responsabilidade objetiva. Rio de Janeiro: Lumen Juris, 2011.

SANTORO-PASSARELI, Francesco. La transazione. 2. ed. Napoli: Jovene, 1963, v. 1.

SARLET, Ingo Wolfgang. A eficácia dos direitos fundamentais. 12. ed. Porto Alegre: Livraria do Advogado, 2015.

SCHEREIBER, Anderson. Novos paradigmas da responsabilidade civil: da erosão dos filtros da reparação à diluição dos danos. 4. ed. São Paulo: Atlas, 2012.

SUNSTEIN, Cass S.; THALER, Richard H. Libertarian Paternalism Is Not an Oxymoron. Civilistica.com. Revista Eletrônica de Direito Civil, Rio de Janeiro, a. 4, n. 2, 2015.

SUNSTEIN, Cass S.; THALER, Richard H. Nudge: improving decisions about health, wealth, and happiness. New Haven: Yale University Press, 2008.

TALAMINI, Eduardo. Tutela relativa aos deveres de fazer e de não fazer e sua extensão aos deveres de entrega da coisa. São Paulo: Revista dos Tribunais, 2003.

TEPEDINO, Gustavo. Liberdades, tecnologia e teoria da interpretação. Revista Forense, Rio de Janeiro: Forense, v. 110, n. 419, jan./jun. 2014.

TEPEDINO, Gustavo. Premissas metodológicas para a constitucionalização do direito civil, In: Temas de Direito Civil. Rio de Janeiro: Renovar, 2008.

TRABUCCHI, Alberto. Istituzioni di diritto civile. 47. ed. Padova: CEDAM, 2015.

VENTURI, Elton. Transação de Direitos Indisponíveis?. Revista de Processo, v. 251, p. 391-428, 2016.

VENTURI, Thaís Gouveia Pascoaloto. Responsabilidade civil preventiva: a proteção contra a violação dos direitos e a tutela inibitória material. São Paulo: Malheiros, 2014.

VINEY, Genevieve. Traité de droit civil: la responsabilité - effets, Paris, LGDJ, 1988.

WALD, Arnoldo. Direito civil. São Paulo: Saraiva, 2015, v. 2.

Recebido: 04.11.2019

Aprovado: 27.11.2019

Como citar: REIS JÚNIOR, Antonio dos. Aplicações da função promocional na responsabilidade civil ambiental. Revista IBERC, Minas Gerais, v. 3, n. 1, p. 1-33, jan./abr. 2020. 